\title{
ISOLATION AND CHARACTERIZATION OF RHIZOBIA AND PLANT GROWTH-PROMOTING RHIZOBACTERIA AND THEIR EFFECTS ON GROWTH OF RICE SEEDLINGS
}

\author{
${ }^{1}$ Tan, K.Z., ${ }^{1}$ O. Radziah, ${ }^{2}$ M.S. Halimi, \\ ${ }^{3}$ A.R. Khairuddin, ${ }^{2}$ S.H. Habib and ${ }^{1}$ Z.H. Shamsuddin \\ ${ }^{1}$ Department of Land Management, Faculty of Agriculture, Universiti Putra Malaysia, Malaysia \\ ${ }^{2}$ Department of Agriculture Technology, Faculty of Agriculture, Universiti Putra Malaysia, Malaysia \\ ${ }^{3}$ Agrotechnology and Biosciences Division, Malaysian Nuclear Agency, Malaysia
}

Received 2014-01-22; Received 2014-01-23; Accepted 2014-04-15

\begin{abstract}
Biofertilizer is a relatively safer, environmentally friendly and cost-effective approach as an alternative to reduce chemical fertilizer usage. The selection of bacterial strains with multiple beneficial characteristics are important to maximize the effectiveness on the host plant. Due to aforementioned interest, several Plant Growth-Promoting Rhizobacterial (PGPR) and rhizobial strains were isolated from rice and legume roots, respectively, at four locations in Malaysia namely Universiti Putra Malaysia (UPM), Serdang, Selangor; Besut, Terengganu; Tunjung, Kelantan and Sik, Kedah. Bacterial isolations were undertaken to select the best isolates which exhibit multiple beneficial effects to the rice plant and a total of 205 bacterial strains were isolated and categorized as follows; 94 rhizospheric and 107 endophytic bacteria from rice roots, one rhizobial strain from soybean and three from Mimosa pudica. These isolates were screened for their abilities to fix $\mathrm{N}_{2}$ and solubilize phosphate; 52 were positive for both tests. The selected isolates were then tested for IAA production and other biochemical tests such as potassium solubilization, hydrolyzing enzymes (cellulase and pectinase) and iron siderophore productions. Four isolates, namely UPMB19 (rhizospheric PGPR from Tunjung, Kelantan), UPMB20 (endophytic PGPR from Besut, Terengganu), UPMR30 (rhizobia from soybean) and UPMR31 (rhizobia from Mimosa) were selected for subsequent plant inoculation tests with UPMB10, a PGPR isolated from oil palm root, as the reference strain. Based on 16S rDNA gene sequencing, these bacterial strains were identified under several genera: Lysinibacillus, Alcaligenes, Bradyrhizobium, Rhizobium and Bacillus, respectively. Results of plant inoculation test indicated that UPMB19 significantly enhanced the seedling height at the early growth stage (7 days after transplanting, DAT) which could be attributed to the higher $\mathrm{N}_{2}$ fixation rate of this strain as compared to the other strains, except UPMB20. UPMB10 and UPMR31 also showed significant effects with increased seedling height and Total Dry Weight (TDW) at the later stage (14 DAT) possibly due to the higher bacterial population and IAA produced as observed in the residual nutrient solution without addition of fertilizer-N. This study has successfully demonstrated the effectiveness of locally isolated PGPR and rhizobial strains with multiple beneficial characteristics on early growth and vigor of rice seedlings under controlled condition. The result proved to be a vital information in the development of a liquid biofertilizer for rice; thus further studies will be done to evaluate the effectiveness of these isolates under glasshouse and field conditions on growth, tillering and yield of rice.
\end{abstract}

Keywords: PGPR, Rhizobia, $\mathrm{N}_{2}$-Fixation, Growth, Rice

Corresponding Author: Shamsuddin, Z.H., Department of Land Management, Faculty of Agriculture, Universiti Putra Malaysia, Malaysia Tel. No.: +603-8947 4964; Fax No.: +603-8947 4919 


\section{INTRODUCTION}

Rice is the major world food crop and it is the most important staple diet for nearly 3 billion people, approximately half of the world population (FAO, 2004). If the consumption trend continues, 4.6 billion people will consume rice by 2025 and production must be increased by $20 \%$ to keep pace with this increasing demand. To increase the local rice yield, farmers tend to apply more chemical fertilizers which can be hazardous to the environment when applied excessively. Alternatively, a relatively safer approach is to use the environmentally friendly biofertilizer which is also cost-effective.

Research on Plant Growth-Promoting Rhizobacteria (PGPR) with non-legumes such as rice have shown beneficial effects through biological $\mathrm{N}_{2}$ fixation (Malik et al., 1997), increased root growth (Mia et al., 2012) with enhanced nutrient uptake (Yanni et al., 1997), phytohormone production (Chabot et al., 1996), plant growth enhancement stimulation by other beneficial bacteria and fungi (Saharan and Nehra, 2011) and disease control (Ramamoorthy et al., 2001). Peng et al. (2002), however, reported that rhizobial inoculation known for their symbiotic relationship with legumes, could also increaserice grain yield, but little is known about the mechanism(s) involved. The beneficial effects of the selected rhizobialisolates could be due to their plant growth-promoting abilities namely biological $\mathrm{N}_{2}$ fixation, phosphate solubilization and plant growthregulator/phytohormone and siderophore production, similar to the known beneficial effects of PGPR (Boddey et al., 1997; Verma et al., 2001; Araujo et al., 2013; Kloepper et al., 1980). Yanni et al. (1997) have also shown beneficial interactions of rhizobial isolateson growth of rice, which was believed to be due to increased root efficiency in water and nutrient uptake.

The reference strain UPMB10 (Bacillus sp.), a local isolate from rhizosphere of oil palm roots, has been studied in detail for the past 10 years. This rhizobacterial isolate has been shown to exhibit several beneficial characteristics namely biological $\mathrm{N}_{2}$ fixation (Mia et al., 2010a), increased accumulation of $\mathrm{N}, \mathrm{P}$ and $\mathrm{K}$ in the plant tissue (Amir et al., 2005), increased root and shoot growth (Mia et al., 2010b) and overall plant growth and yield (Farzana et al., 2007) on various crops such as oil palm, sweetpotato, banana and rice (Amir et al., 1999; Farzana et al., 2009; Mia et al., 2009; 2012). ${ }^{15} \mathrm{~N}$ dilution technique and acetylene reduction assay revealed that the $\mathrm{BNF}$ rate values to be 28 and $63 \%$, respectively
(Amir et al., 2003; Zakry et al., 2012). The large variation of nitrogen derived from atmosphere (Ndfa) values are due to the solid substrate used in the later study as compared to the liquid inoculum used in the earlier report. The solid substrate was reported to have several advantages over liquid inoculum as it provides a substantial amount of carbon source, incubated for 2 weeks prior to application and organic substrate in the carrier which provide 'shelter' for bacterial cells from direct sunlight and act as a buffer zone (Zakry et al., 2012).

Thus, it is essential to isolate native rhizobia and PGPR from rice grown fields for multiple beneficial effects on the crops and for potential biofertilizer development. In the present study, isolation and screening of local rhizobia and PGPR with multiple plant growth-promoting abilities were conducted, followed by in vitro plant inoculation test.

\section{MATERIALS AND METHODS}

\subsection{Sampling of Rice and Legume Roots for Bacterial Isolation}

At every location, eight sampling points, each point approximately $50 \mathrm{~m}$ apart, were randomly selected. One healthy rice plant per point was chosen for bacterial isolation. The roots were washed twice with clean water to remove the adhering soil particles. Three fresh and whitish root tips, each approximately $2.5 \mathrm{~cm}$ long, were cut and placed into a test tube containing $9 \mathrm{~mL}$ sterile distilled water. The test tubes were shaken manually to remove soil particles and other debris on the roots and the water was replaced with new sterile distilled water. The samples were taken to the laboratory in an ice box, the icereplaced regularly every $6 \mathrm{~h}$.

Volunteer leguminous plants (Glycine max, Mimosa pudica) in therice field were collected randomly and thenodules from each plant were removed and placed in McCartney bottles containing $15 \mathrm{~mL}$ sterile distilled water. The bottles were stored in ice box and taken to the laboratory.

\subsection{Isolation of Rhizobia/PGPR}

The rice root samples were transferred into McCartney bottles containing $15 \mathrm{~mL}$ sterile distilled water using sterile forceps. The bottles were shaken vigorously with a vortex mixer for $10 \mathrm{sec}$. The solutions were used to isolate rhizospheric bacteria. The roots were taken out and surface sterilized by soaking in $95 \%$ ethanol for $10 \mathrm{sec}$, followed by $3 \%$ sodium hypochlorite for 1 min. 6 times washed with sterile distilled water. Then, the roots were cut 
longitudinally using sterile blade, followed by vertical sections into 5 pieces. These dissected root pieces were transferred into another McCartney bottle containing $15 \mathrm{~mL}$ sterile distilled water and the bottle shaken vigorously with a vortex mixer for $10 \mathrm{sec}$. These solutionswere used to isolate for endophytic bacteria.

The above procedures were repeated for all 8 rice plants from each sampling location. $0.1 \mathrm{~mL}$ of the solution from each bottle wastransferred onto Tryptic Soy Agar (TSA) plates and spread evenly using a hockey stick. The plates were covered with parafilm, inverted and placed in the incubator for $24 \mathrm{~h}$ at $33^{\circ} \mathrm{C}$.

Similarly, nodules from the leguminous plants were surface sterilized, dissected and crushed using a sterile pestle. It was transferred into a test tube containing $9 \mathrm{~mL}$ sterile distilled water and shaken using a vortex mixer. 0.1 $\mathrm{mL}$ of the solution from each tube was pipetted into Yeast Mannitol Agar (YMA) plate and spread evenly using a hockey stick. The plates were covered with parafilm, inverted and placed in the incubator for $24 \mathrm{~h}$ at $33^{\circ} \mathrm{C}$.

After $24 \mathrm{~h}$, all the plates were observed for different types of bacterial growth, based on colony morphology such as color and shape. Different colonies were subcultured into new TSA/YMA several times to get the pure, single colony. Each of the isolates was transferred onto agar slant (TSA/YMA) and kept in the refrigerator at $-3^{\circ} \mathrm{C}$ for the next subsequent experiment.

\section{3. $\mathbf{N}_{2}$ Fixation Ability}

The $\mathrm{N}_{2}$ fixation ability was tested by growing the isolates on $\mathrm{N}$-free solid malate medium ( $\mathrm{Nfb}$ medium) according to the method by Dobereiner and Day (1975). Plates were incubated for $24 \mathrm{~h}$ at $33^{\circ} \mathrm{C}$. The ability of the isolates to fix $\mathrm{N}_{2}$ was observed by the change in color of the media from pale green to blue after the incubation period. This is due to the increase in $\mathrm{pH}$ attributed to the formation of ammonia and nitrates from the atmospheric $\mathrm{N}_{2}$ fixation.

The quantitative measurement of $\mathrm{N}_{2}$ fixation rate of the selected bacterial strains was done using Acetylene Reduction Assay (ARA) method according to Hardy et al. (1968) and Somasegaran and Hoben (1985). About 20 $\mu \mathrm{L}$ of the bacterial inoculum $\left(1 \times 10^{8} \mathrm{CFU} \mathrm{mL} \mathrm{mL}^{-1}\right)$ was transferred into a $10 \mathrm{~mL}$ Vacutainer (Becton, Dickinson and Company, USA) containing $4 \mathrm{~mL}$ of $\mathrm{N}$-free semi solid media (Dobereiner and Day, 1975). 10\% of the air was replaced with pure acetylene gas $(99.8 \%)$ using a gas-tight syringe (Hamilton ${ }^{\circledR}$, USA). The bacterial culture was allowed to incubate for $1 \mathrm{~h}$ and $1 \mathrm{~mL}$ of the air sample was injected into a gas chromatography
(7820A, Agilent Technologies, USA) equipped with a hydrogen Flame Ionization Detector (FID) and stainless steel column with Porapak $\mathrm{N}$ media. The concentration of ethylene produced was calculated based on the standard ethylene graph at $2.1 \mathrm{~min}$ Retention Time (RT).

\subsection{Phosphate Solubilizing ability}

The isolated culture was grown on Pikovskaya medium to determine the ability to solubilize phosphate according to the method by Pikovskaya (1948). The ability to solubilize phosphate was observed by the formation of a halo zone around the colony $(10 \mu \mathrm{L}$

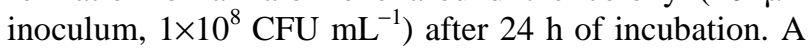
halo zone will be formed when the bacterial isolates produce organic acid which will solubilize tri-calcium phosphate in the medium.

The quantification of the solubilized phosphate was undertaken by using phosphate solubilizing index, according to the method by Sitepu et al. (2007). Phosphate solubilization index was derived by dividing the total diameter of the halo zone (colony+halo zone) with diameter of the colony. These were undertaken in triplicates.

The phosphate solubilization quantification was repeated using vanadomolybdophosphoric acid method (Kumar et al., 2009; Ribeiro and Cardoso, 2012) to measure soluble phosphate concentration in the culture supernatants of NBRIP broth (Nautiyal, 1999). The standard curve was prepared by a stock solution of $\mathrm{KH}_{2} \mathrm{PO}_{4}$, mixed with $5 \mathrm{~mL}$ of concentrated $\mathrm{H}_{2} \mathrm{SO}_{4}$ and diluted to $1 \mathrm{~L}$ with distilled water. The bacterial isolates were grown on TSA culture medium for $24 \mathrm{~h}$. Thereafter, $10 \mu \mathrm{L}$ of bacterial suspension (containing

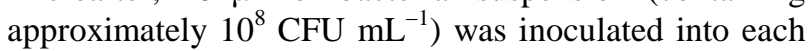
NBRIP broth. The control consisted of flasks containing $100 \mathrm{~mL}$ of NBRIP culture medium without inoculum. The flasks were incubated at $28^{\circ} \mathrm{C}$ for 12 days under constant agitation at $100 \mathrm{rpm}$ and the $\mathrm{pH}$ of the culture medium in each treatment was checked. After 6 days of incubation, 25 $\mathrm{mL}$ of each culture medium was added to $50 \mathrm{~mL}$ centrifuge tubes, which were centrifuged at $8000 \mathrm{~g}$ for $20 \mathrm{~min} .2 .5 \mathrm{~mL}$ of the supernatant was transferred into a $50 \mathrm{~mL}$ beaker and $20 \mathrm{~mL}$ of distilled water was added. $2.5 \mathrm{~mL}$ of Barton's reagent (Barton, 1948) was added quickly to create a mixing action and color development was allowed for 10 min. The absorbance value was determined colorimetrically using spectrophotometer at $430 \mathrm{~nm}$. The same procedures were repeated after 12 days of incubation. The long incubation periods (6 and $12 \mathrm{DAI}$ ) were chosen as the preliminary study revealed that these bacterial strains have slow rate of phosphate solubilization ability. 


\subsection{Phytohormone Production}

Fully grown bacterial cultures were inoculated in 100 $\mathrm{mL}$ Tryptic Soy Broth (TSB) and shaken on an orbital shaker for $24 \mathrm{~h} .1 \mathrm{~mL}$ of the bacterial culture was transferred into a new $100 \mathrm{~mL}$ TSB with the addition of $5 \mathrm{~mL}$ L-Tryptophan as the precursor of Indole-3-acetic Acid. TSB without bacterial inoculation served as the control. $1.5 \mathrm{~mL}$ of the bacterial culture were transferred into sterile Appendorf tube and centrifuged at $7000 \mathrm{rpm}$ for $7 \mathrm{~min}$. The supernatant $(1 \mathrm{~mL})$ wasmixedwith $2 \mathrm{~mL}$ of Salkowsky reagent (2\% of $0.5 \mathrm{M} \mathrm{FeCl}_{3}$ in $35 \%$ perchloric acid) according to the method by Gordon and Weber (1951). The solution was allowed to settle for 25 min and development of a pink color would indicate IAA production. The absorbance values were determined using a spectrophotometer at $535 \mathrm{~nm}$ and compared to the standard curve to determine the IAA concentration. The IAA standard curve was prepared using pure IAA at $0,5,10,15,20,25,30,35,40$ and $45 \mu \mathrm{g} \mathrm{mL} L^{-1}$ of IAA. Supernatants of uninoculated test tubes were used as control, where no visible color was observed.

\subsection{Potassium Solubilization Ability}

The selected isolates were grown on a modified Aleksandrov agar medium to determine the ability to solubilize potassium (Hu et al., 2006). About $10 \mu \mathrm{L}$ of bacterial suspension (containing approximately $10^{8}$ $\mathrm{CFUmL}^{-1}$ ) were streaked onto the media, incubated at $33^{\circ} \mathrm{C}$ and observed at 5 and 10 Days After Incubation (DAI). The ability to solubilize muscovite mica as a source of insoluble form of potassium was derived by the formation of clear halo zone around the colony.

The quantitative estimation of potassium solubilization rate was examined based on the bacterial abilities to release $\mathrm{K}$ from media supplemented with muscovite mica as an insoluble source of potassium. One $\mathrm{mL}$ of overnight culture of each isolate was inoculated to $100 \mathrm{~mL}$ of Aleksandrov broth and the amount of $\mathrm{K}$ released in the broth was estimated at 5, 10 and 15 DAI from triplicate flasks, in comparison with a set of uninoculated control. The broth cultures were centrifuged at $10,000 \mathrm{rpm}$ for $10 \mathrm{~min}$ to separate the supernatant from the bacterial cells and insoluble potassium. The available $\mathrm{K}$ content in the supernatant was determined by Atomic Absorption Spectrometer (AAS) (Perkin Elmer, AAnalyst 400 AAS). One $\mathrm{mL}$ of the supernatant was taken in a $50 \mathrm{~mL}$ volumetric flask and the volume was made to $50 \mathrm{~mL}$ with distilled water and mixed thoroughly. Then, the solution was fed to AAS for K content determination.

\subsection{Iron Sequestration (Siderophore Production)}

Chrome Azurol S (CAS) agar similar to that described by Schwyn and Neilands (1987) was prepared to detect the siderophore production by the bacteria.

CAS agar plates were spot inoculated with each of the bacterial strain and incubated for $48 \mathrm{~h}$ at $33^{\circ} \mathrm{C}$. Development of an orange halo zone around the colony (10 $\mu \mathrm{L}$ inoculum, $1 \times 10^{8} \mathrm{CFU} \mathrm{mL}^{-1}$ ) indicates a positive result as the siderophore removes $\mathrm{Fe}$ from the Fe-CAS dye complex and gives the medium its characteristic blue color.

\subsection{Cellulase Enzyme Production}

Carboxy Methyl Cellulose (CMC) agar plates were prepared by screening for cellulose enzyme production according to the method by Kasana et al. (2008).

A sterile paper disc was dipped into microbial culture and transferred onto the CMC agar plates. The plates were incubated overnight at $33^{\circ} \mathrm{C}$. After incubation, the plates were flooded with Congo red solution for $15 \mathrm{~min}$, followed by de-staining with the salt solution for $15 \mathrm{~min}$. Unstained areas indicate where the CMC has been degradeddue to production of cellulose by the bacterial strain.

\subsection{Pectinase Enzyme Production}

Pectinase agar plates were prepared to screen for pectinase enzymes production, according to the method by Yogesh et al. (2009).

A sterile paper disc was dipped into microbial culture and transferred onto the pectinase agar plates. The plates were incubated overnight at $33^{\circ} \mathrm{C}$. After incubation, the plates were flooded with $50 \mathrm{mM}$ iodine solution for 15 min to observe the halo zonewhich indicates the ability of the strain to produce pectinase enzyme.

\subsection{Bacterial Identification using $16 \mathrm{~S}$ rDNA Gene Sequence}

The selected strains were identified by partial sequencing of the 16S rDNA gene. Genomic DNA was isolated from the bacterial culture by using Genomic DNA Mini Kit (Geneaid). 16S rDNA gene was amplified using universal forward (5'AGAGTTTGATCMTGGCTCAG-3') and reverse (5'GGTTACCTTGTTACGACTT-3) primers (Integrated DNA Technologies, USA). $50 \mu \mathrm{L}$ reaction mixture was prepared containing $5 \mu \mathrm{L}$ of DNA template, $5 \mu \mathrm{L} 10 \mathrm{X}$ 
PCR Reaction Buffer, $0.75 \mu \mathrm{L} 10 \mu \mathrm{M}$ of each primers, 1 $\mu \mathrm{L} 10 \mu \mathrm{M}$ dNTPs mix, $0.5 \mu \mathrm{L} 5 \mu / \mu \mathrm{L}$ Taq polymerase, $3 \mu \mathrm{L} 25 \mu \mathrm{M} \mathrm{MgCl}_{2}$ and $34 \mu \mathrm{L}$ ultra-pure water. PCR reactions were carried out in a thermal cycler (MJ Mini Personal Thermal Cycler, Bio-Rad) using cycles as follows: $5 \mathrm{~min}$ at $94^{\circ} \mathrm{C}, 30 \mathrm{sec}$ at $94^{\circ} \mathrm{C}, 30 \mathrm{sec}$ at $55^{\circ} \mathrm{C}, 1$ min at $72^{\circ} \mathrm{C}$ and final extension for $5 \mathrm{~min}$ at $72^{\circ} \mathrm{C}$. The amplified 16S rDNA gene was purified with a Gel/PCR DNA Fragments Extraction Kit (Geneaid) and outsourced for sequencing (First Base Laboratories Pvt. Ltd., Selangor, Malaysia). The sequence data was aligned and analyzed to identify the bacterium and its closest neighbors by using BLAST (NCBI, USA).

\subsection{Plant Inoculation Test in Plant Growth Chamber}

Bacterial cultures were prepared by growing them in $\mathrm{TSB} / \mathrm{YMB}$ for $24 \mathrm{~h}$, followed by centrifuging at $4000 \mathrm{~g}$ for $40 \mathrm{~min}$. The supernatants were then removed aseptically and replaced with $20 \mathrm{~mL} 0.85 \%$ sterile phosphate buffer saline.

Table 1. Treatment design and description of the plant inoculation test (Control/PGPR and rhizobia)

\begin{tabular}{ll}
\hline Treatment & Description \\
\hline T1: $\mathrm{N}_{0}-$ PGPR & Control 1 (without N) \\
T2: $\mathrm{N}_{33}-$ PGPR & Control 2 (with 33\% of N) \\
T3: $\mathrm{N}_{0}+$ PGPR 1 & UPMB19 \\
T4: $\mathrm{N}_{0}+$ PGPR 2 & UPMB20 \\
T5: $\mathrm{N}_{0}+$ PGPR 3 & UPMR30 \\
T6: $\mathrm{N}_{0}+$ PGPR 4 & UPMR31 \\
T7: $\mathrm{N}_{0}+$ PGPR 5 & UPMB10 \\
T8: $\mathrm{N}_{33}+$ PGPR 1 & UPMB19 \\
T9: $\mathrm{N}_{33}+$ PGPR 2 & UPMB20 \\
T10: $\mathrm{N}_{33}+$ PGPR 3 & UPMR30 \\
T11: $\mathrm{N}_{33}+$ PGPR 4 & UPMR31 \\
T12: $\mathrm{N}_{33}+$ PGPR 5 & UPMB10
\end{tabular}

Note: [All treatments were laid in Completely Randomized Design (CRD) with three replicates and harvested after 7 and 14 Days of Transplanting (DAT); N0: Treatment without inorganic fertilizer-N, N33: Treatment with $33 \%$ of inorganic fertilizer-N recommended rate]

Table 2. Rhizobial and PGPR strains used for inoculation of rice variety MR219

\begin{tabular}{|c|c|c|}
\hline Strains & Species & Isolated plant species \\
\hline UPMB10 & Bacillus sp. & Elaeis guineensis Jacq. \\
\hline UPMB19 & $\begin{array}{l}\text { Rhizospheric PGPR strain } \\
\text { isolated from rice roots }\end{array}$ & Oryza sativa $L$. \\
\hline UPMB20 & $\begin{array}{l}\text { Endophytic PGPR strain } \\
\text { isolated from rice roots }\end{array}$ & Oryza sativa $L$. \\
\hline UPMR30 & Rhizobial strain & Glycine $\max$ \\
\hline UPMR31 & Rhizobial strain & Mimosa pudica \\
\hline
\end{tabular}

The solution was mixed thoroughly using vortex mixer for $30 \mathrm{sec} .1 \mathrm{~mL}$ of the bacterial suspension from each solution was transferred into a series of test tubes at 10-fold dilutions each and streaked on TSA/YMA to get the Colony Forming Unit (CFU) by total plate count technique, according to method by Somasegaran and Hoben (1985). The optical densitiesof the bacterial cultures were also undertaken by transferring $1.5 \mathrm{~mL}$ of the bacterial suspension into $2 \mathrm{~mL}$ cuvette and read using a spectrophotometer at $600 \mathrm{~nm}$ absorbance.

Sets of sterile $500 \mathrm{~mL}$ measuring cylinders and stainless steel sieves were prepared for growth of the rice seedlings according to the method by Egener et al. (1999). About $50 \mathrm{~mL}$ sterile $\mathrm{N}$-free nutrient solutions were added to each cylinder followed by $5 \mathrm{~mL}$ of the respective phosphate buffer saline-washed bacterial inoculum, according to the treatments (approximately $10^{7-8} \mathrm{CFU} \mathrm{\textrm {mL } ^ { - 1 }}, 1 \mathrm{~mL}$ per seedling) (Table 1 and 2). Five 5-days old rice seedlings were aseptically transferred onto the sieve in the cylinder and adjusted so that only the roots were in contact with the nutrient solution. The lids of the cylinders were covered with aluminium foil and incubated in a plant growth chamber at $30^{\circ} \mathrm{C}$ for 14 days with alternate $12 \mathrm{~h}$ day and night cycle.

\subsection{Statistical Analysis}

Data on phosphate solubilization index, phytohormone production and plant inoculation test in theplant inoculation experiment were subjected to Analysis of Variance (ANOVA) using SAS software. Means were compared by Least Significant Difference (LSD) Test at a probability level of 0.05 .

\section{RESULTS}

A total of 205 isolates were obtained from this study, which came from four distinct locations across Malaysia. The bacterial isolates were categorized as follows; 94 rhizospheric and 107 endophytic bacteria from rice roots, one rhizobial strain from soybean (Glycine max) and three from Mimosa pudica (Table 3). The highest number of PGPR was isolated from Besut, Terengganu, followed by UPM, Selangor, Tunjung, Kelantan and Sik, Kedah with a total number of 93, 45, 41 and 22 isolates, respectively. Results also showed that sampling sites with long history of rice cultivation namely at Tunjung, Kelantan and Besut, Terengganu tend to have higher numbers of endophytes from the total isolates (60-61\%), compared to the relatively new rice cultivation sites at Sik, Kedah and UPM, Selangor (27-44\%). Fifty two of these bacterial isolates were positive for both the $\mathrm{N}_{2}$ fixation and phosphate solubilization ability tests using agar plates (Table 4 and Fig. 1). 
Tan, K.Z. et al. / American Journal of Agricultural and Biological Sciences 9 (3): 342-360, 2014

Table 3. Rhizospheric and endophytic classification and distribution of bacterial isolates from four locations

\begin{tabular}{|c|c|c|c|c|}
\hline Location & Crop & Classification & Isolates & Percentage \\
\hline \multirow[t]{3}{*}{ Sik, Kedah } & Oryza sativa & Rhizospheric & 16 & 73 \\
\hline & & Endophytic & 6 & 27 \\
\hline & Total isolates & & 22 & 100 \\
\hline \multirow[t]{3}{*}{ Tunjung, Kelantan } & Oryza sativa & Rhizospheric & 16 & 39 \\
\hline & & Endophytic & 25 & 61 \\
\hline & Total isolates & & 41 & 100 \\
\hline \multirow[t]{3}{*}{ UPM, Selangor } & Oryza sativa & Rhizospheric & 25 & 56 \\
\hline & & Endophytic & 20 & 44 \\
\hline & Total isolates & & 45 & 100 \\
\hline \multirow[t]{3}{*}{ Besut, Terengganu } & Oryza sativa & Rhizospheric & 37 & 40 \\
\hline & & Endophytic & 56 & 60 \\
\hline & Total isolates & & 93 & 100 \\
\hline Total PGPR isolates collected & & 201 & - & \\
\hline \multirow[t]{2}{*}{ UPM, Selangor } & Glycine $\max$ & Root nodule (legume) & 1 & 25 \\
\hline & Mimosa pudica & & 3 & 75 \\
\hline Total Rhizobial isolates collected & & & 4 & 100 \\
\hline
\end{tabular}

Table 4. $\mathrm{N}_{2}$-fixation and phosphate solubilization tests result

\begin{tabular}{lcl}
\hline Location & Isolates & Positive tests on $\mathrm{N}_{2}$-fixation and phosphate solubilization \\
\hline Sik, Kedah & 22 & $4(18.2 \%)$ \\
Tunjung, Kelantan & 41 & $12(29.3 \%)$ \\
UPM, Selangor & 49 & $6(12.2 \%)$ \\
Besut, Terengganu & 93 & $30(32.3 \%)$ \\
Total & 205 & $52(25.4 \%)$ \\
\hline
\end{tabular}

Note: [Figures in parenthesis represent the percentage values per location]

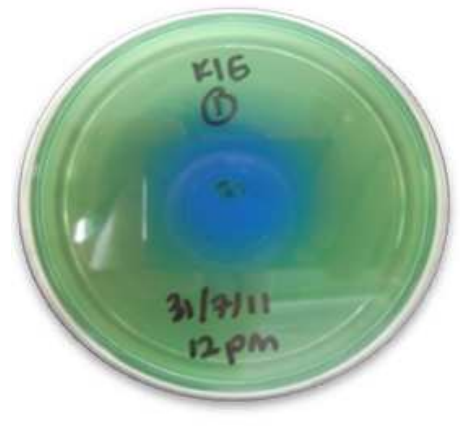

$\mathrm{N}$-free agar plate

(a)

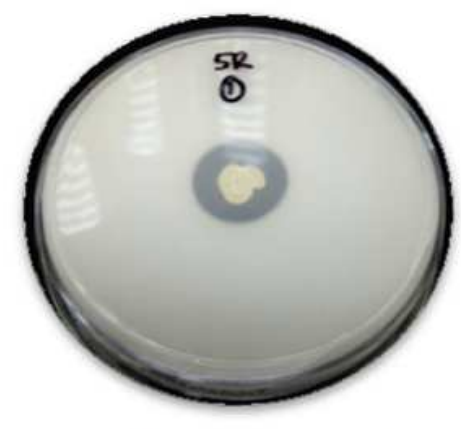

Pikovskaya agar plate

(b)

Fig. 1. N-free(a) and Pikovskaya(b) agar plates after inoculation with selected isolates for 24 h. Positive indications are shown by the change in color from green to blue in (a) and formation of halo zone around the colony in $b$

A total of 52 isolates $(25.4 \%)$ from the total of 205 isolates have dual beneficial characteristics namely $\mathrm{N}_{2}$ fixation and phosphate solubilization.

Based on the IAA production, five isolates were selected, namely UPMB19 (Tunjung rhizospheric PGPR), UPMB20 (Besut endophytic PGPR), UPMR30 (UPM Soybean) and UPMR31 (UPM Mimosa) and the reference strain UPMB10, which produced 23.681, $3.327,13.225,8.932$ and $19.670 \mu \mathrm{g} \mathrm{mL}{ }^{-1}$ of IAA, respectively (Table 5).
The five isolates from the current study were then subjected to other biochemical tests such as quantification of $\mathrm{N}_{2}$ fixation, phosphate and potassium solubilization rates and qualitative observation of siderophore and hydrolyzing enzyme production by using Acetylene Reduction Assay (ARA), phosphate solubilization index and vanadomolybdophosphoric acid method, Aleksandrov broth media, Chrome Azurol $\mathrm{S}(\mathrm{CAS})$, cellulase and pectinase agar, respectively. 
Tan, K.Z. et al. / American Journal of Agricultural and Biological Sciences 9 (3): 342-360, 2014

Table 5. IAA production of the selected PGPR/rhizobial isolates

\begin{tabular}{|c|c|c|c|c|c|}
\hline No & Isolates & IAA $(\mu \mathrm{g} / \mathrm{mL})$ & No. & Isolates & IAA $(\mu \mathrm{g} / \mathrm{mL})$ \\
\hline 1 & UPM r 1 & 1.460 & 27 & Besut e 14 & 1.212 \\
\hline 2 & UPM r 2 & 2.175 & 28 & Besut e 15 & 7.424 \\
\hline 3 & UPM r 3 & 1.303 & 29 & Besut e 16 & 7.052 \\
\hline 4 & UPM Mimosa 1 (UPMR31) & 8.932 & 30 & Besut e 17 & 1.929 \\
\hline 5 & UPM Mimosa 2 & 1.367 & 31 & Besut e 18 & 0.994 \\
\hline 6 & UPM Soybean 1 (UPMR30) & 13.225 & 32 & Besut e 19 & 0.808 \\
\hline 7 & Besut $r 1$ & 4.131 & 33 & Besut e 20 & 7.207 \\
\hline 8 & Besut $\mathrm{r} 2$ & 1.242 & 34 & Besut e 21 & 0.870 \\
\hline 9 & Besut $\mathrm{r} 3$ & 1.895 & 35 & Besut e 22 & 2.299 \\
\hline 10 & Besut $\mathrm{r} 4$ & 2.361 & 36 & Besut e 23 & 0.870 \\
\hline 11 & Besut r 5 & 1.957 & 37 & Tunjung r 1 (UPMB19) & 23.681 \\
\hline 12 & Besut r 6 & 8.553 & 38 & Tunjung $\mathrm{r} 2$ & 4.611 \\
\hline 13 & Besut $\mathrm{r} 7$ & 8.560 & 39 & Tunjung $\mathrm{r} 3$ & 3.903 \\
\hline 14 & Besut e 1 & 0.932 & 40 & Tunjung e 1 & 2.442 \\
\hline 15 & Besut e 2 & 0.777 & 41 & Tunjung e 2 & 2.730 \\
\hline 16 & Besut e 3 & 1.304 & 42 & Tunjung e 3 & 1.912 \\
\hline 17 & Besut e 4 & 1.336 & 43 & Tunjung e 4 & 3.040 \\
\hline 18 & Besut e 5 & 1.367 & 44 & Tunjung e 5 & 4.788 \\
\hline 19 & Besut e 6 & 2.799 & 45 & Tunjung e 6 & 3.283 \\
\hline 20 & Besut e 7 (UPMB20) & 23.327 & 46 & Tunjung e 7 & 5.451 \\
\hline 21 & Besut e 8 & 0.683 & 47 & Tunjung e 8 & 4.633 \\
\hline 22 & Besut e 9 & 1.646 & 48 & Tunjung e 9 & 5.584 \\
\hline 23 & Besut e 10 & 3.666 & 49 & Sik r 1 & 4.013 \\
\hline 24 & Besut e 11 & 1.469 & 50 & Sik r 2 & 4.500 \\
\hline 25 & Besut e 12 & 6.151 & 51 & Sik e 1 & 3.571 \\
\hline \multirow[t]{2}{*}{26} & Besut e 13 & 7.518 & 52 & Sik e 2 & 4.080 \\
\hline & & & & Reference strain (UPMB10) & 19.670 \\
\hline
\end{tabular}

Note: [Values are based on average of 3 replicates; "r" represent rhizospheric PGPR, "e" endophytic PGPR]

The results of ARA showed a considerable amount of ethylene produced by the selected strains which ranged between 15.60-19.95 nmol $\mathrm{C}_{2} \mathrm{H}_{4} / \mathrm{mL} /$ hour (Fig. 2). UPMB19 and UPMB20 have significantly higher nitrogenase activities with an increment of $28 \%$ and $24 \%$, respectively, compared to the lowest ethylene produced by UPMB 10 .

Phosphate solubilization index showed that isolate UPMB10 has significantly the highest phosphate solubilization index compared to the other isolates throughout the incubation period of 10 days (Fig. 3). The values gradually increased from 2.14 at two days after incubation (D2) to 2.51 at the end of the incubation period (D10). Similar trend was observed for strain UPMB20 with increment of index value from 1.31 to 2.00. Other isolates, UPMB19 and UPMR31, recorded a gradual increase in index value from $\mathrm{D} 2$ to $\mathrm{D} 8$, followed by a slight decline at D10. UPMR30 also recorded an increase from D2 to D4, followed by a gradual decline until D10.

The quantification of phosphate solubilization by the bacteria in the current study was repeated using a relatively more accurate technique called vanadomolydophosphoric acid method. The amount of soluble phosphate derived from the solubilization of insoluble form of phosphate [tricalcium phosphate, $\left.\mathrm{Ca}_{3}\left(\mathrm{PO}_{4}\right)_{2}\right]$ was measured. All inoculums media (NBRIP broth) showed a continuous drop in $\mathrm{pH}$ upon bacterial inoculation and prolonged incubation period (Fig. 4). The $\mathrm{pH}$ of the uninoculated broth remained constant at 7.0 throughout the duration of the 12-days experiment. The amount of $\mathrm{P}$ solubilized was directly related to the drop in media $\mathrm{pH}$. Inoculation with strain UPMR31 showed the highest drop of $\mathrm{pH}(25 \%)$ at 12 Days After Incubation (DAI), compared to the $\mathrm{pH}$ at 6 DAI, followed by the broth inoculated with UPMB 10 which 
showed a $\mathrm{pH}$ drop rate of $9.7 \%$. At 6 DAI, UPMB10 reduced the $\mathrm{pH}$ of media to 5.45 which was the lowest among the treatment and this resulted in a significantly high inorganic phosphate solubilization $\left(51.14 \mu \mathrm{g} \mathrm{mL}^{-1}\right.$ P) compared to the other strains Fig. 5. However, upon prolonged incubation, UPMR31 reduced the media $\mathrm{pH}$ to the lowest value at 4.71 and hence produced the highest phosphate solubilization rate $\left(61.87 \mu \mathrm{g} \mathrm{mL}^{-1}\right)$. This was also true for inoculation with UPMB10, with the drop in $\mathrm{pH}$ to 4.92 and the rate of phosphate solubilization at $56.59 \mu \mathrm{g} \mathrm{mL}^{-1}$.

Amount of K solubilized by these bacterial strains

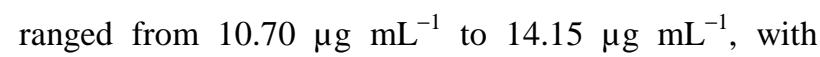
UPMB10 able to significantly solubilize the highest $\mathrm{K}$, followed by UPMB19, UPMB20, UPMR30 and UPMR31 (Fig. 6). He selected isolates were also tested for other biochemical tests such as siderophore and hydrolyzing enzyme production (Table 6 and Fig. 7). All isolates were able to produce siderophose, with UPMB19 and UPMB20 showing a slightly higher production rates through the halo zone observation. Meanwhile, isolates UPMB10, UPMB19 and UPMB20 were able to secrete cellulase while the ability to produce pectinase only existed for the latter strain.

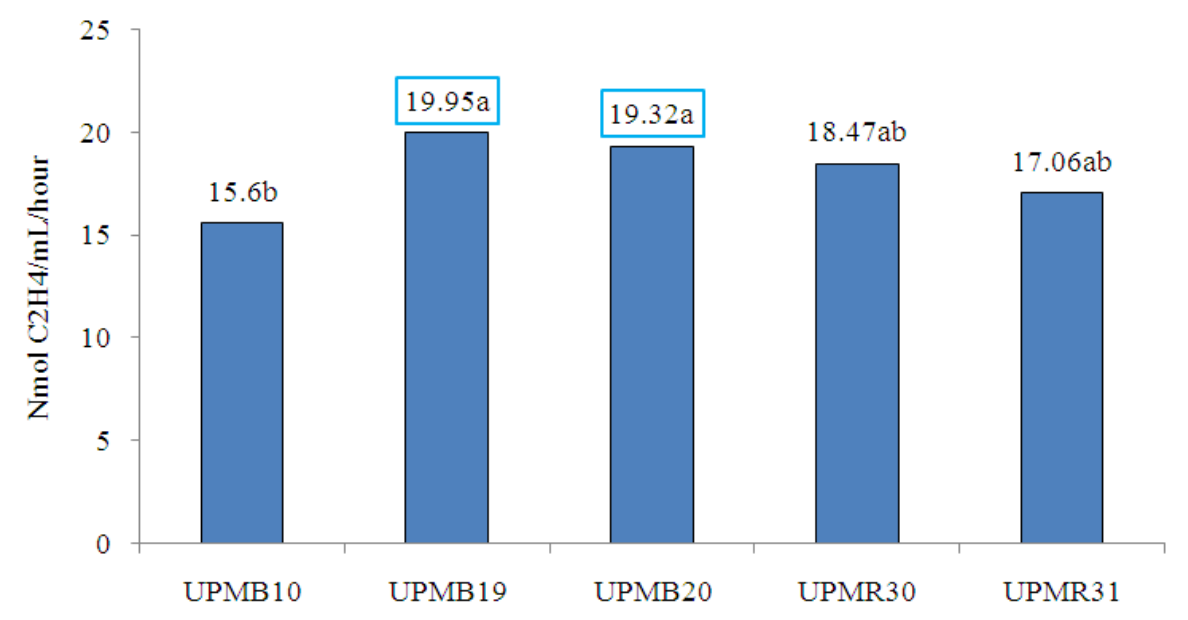

Fig. 2. Acetylene reduction assay of the selected isolates Note: Different letters within each column are significantly different at 0.05 level

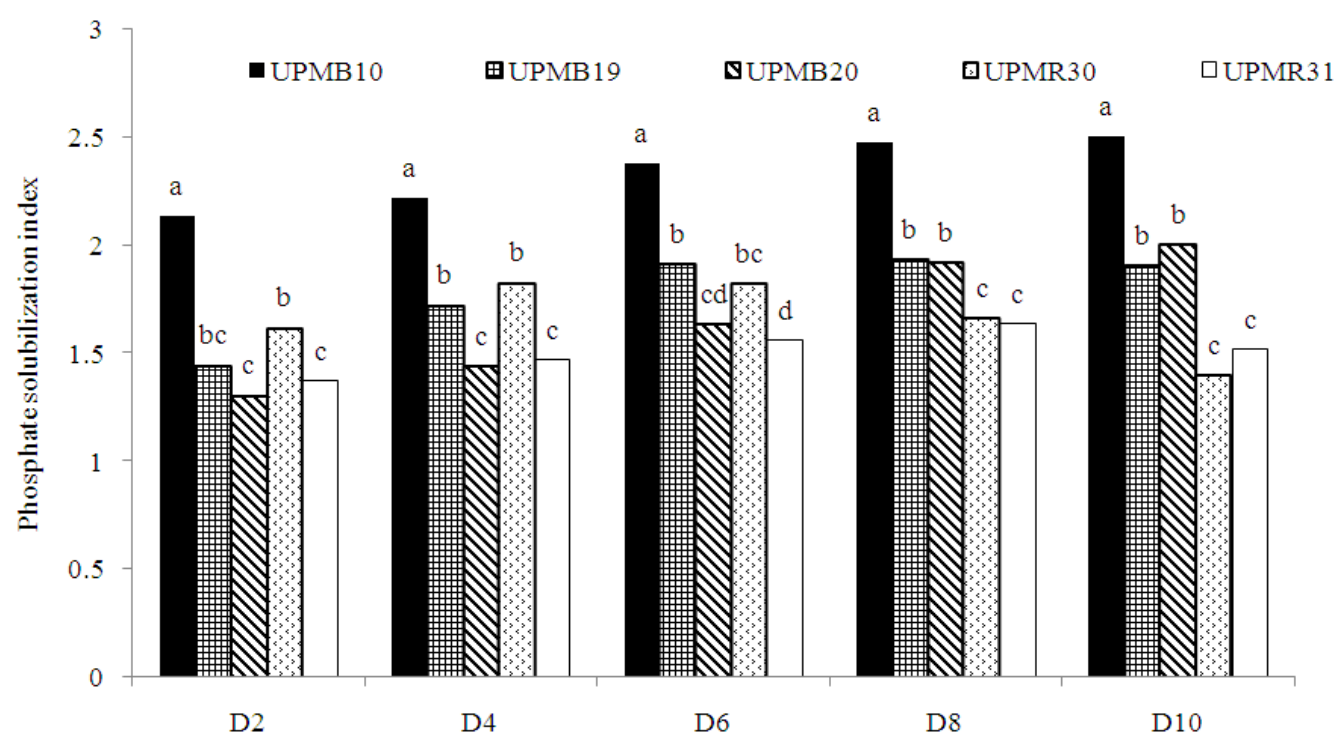

Fig. 3. Phosphate solubilization index of the selected isolates Note: Different letters within each column are significantly different at 0.05 level 
Tan, K.Z. et al. / American Journal of Agricultural and Biological Sciences 9 (3): 342-360, 2014

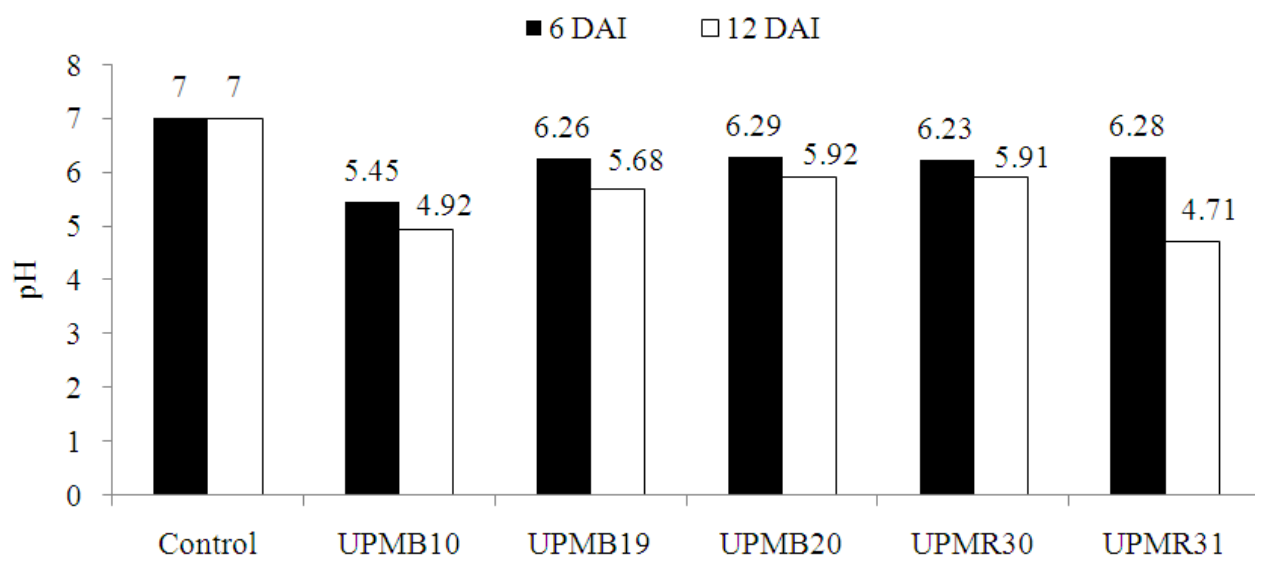

Fig. 4. Changes in $\mathrm{pH}$ of the medium by bacterial inoculations

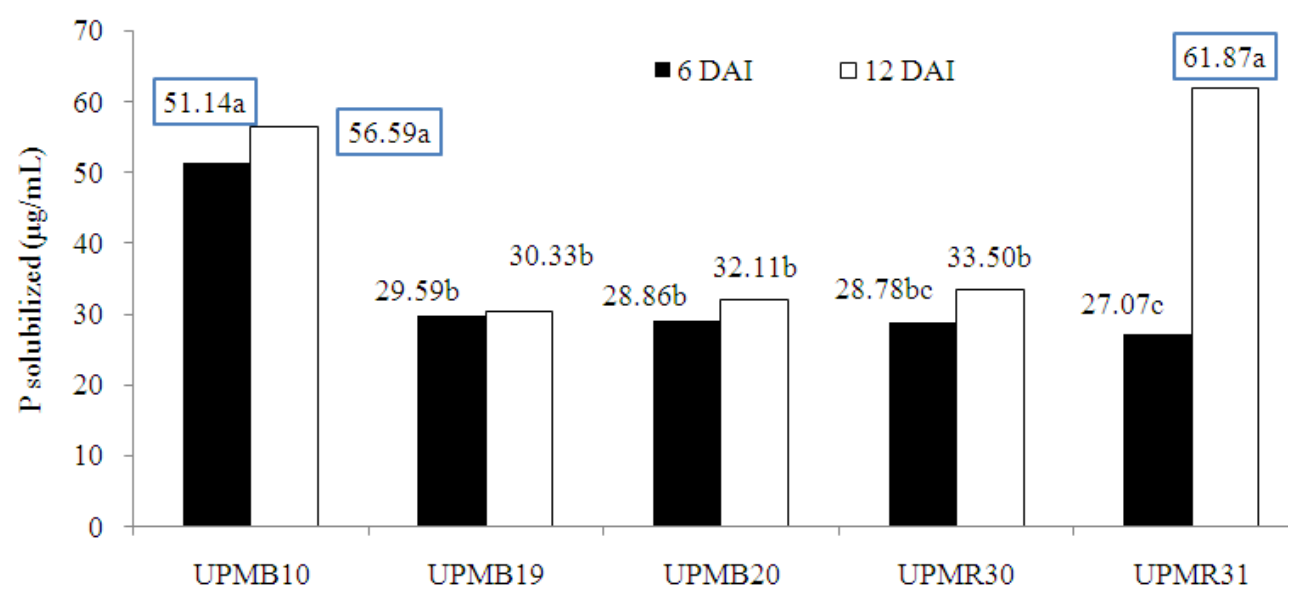

Fig. 5. Phosphate solubilization rate of the selected isolates Note: Different letters within each column are significantly different at 0.05 level

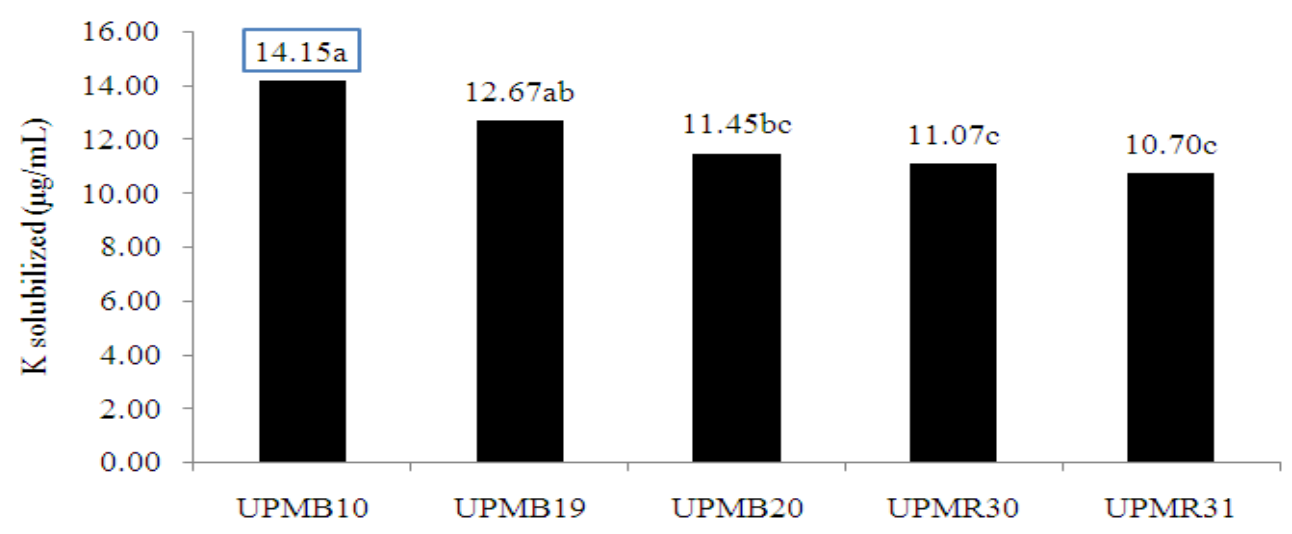

Fig. 6. Potassium solubilization rate of the selected isolates at 5 DAI Note: Different letters within each column are significantly different at 0.05 level 


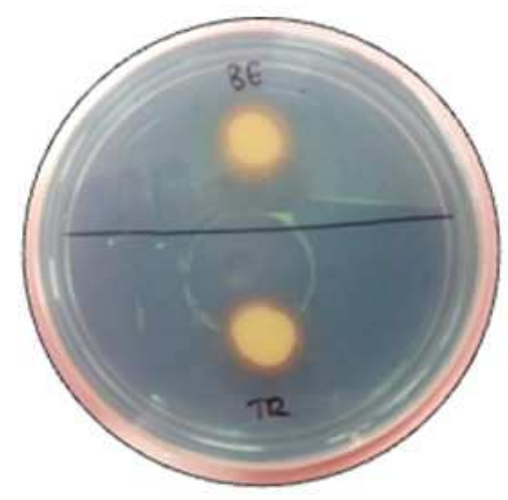

(a)

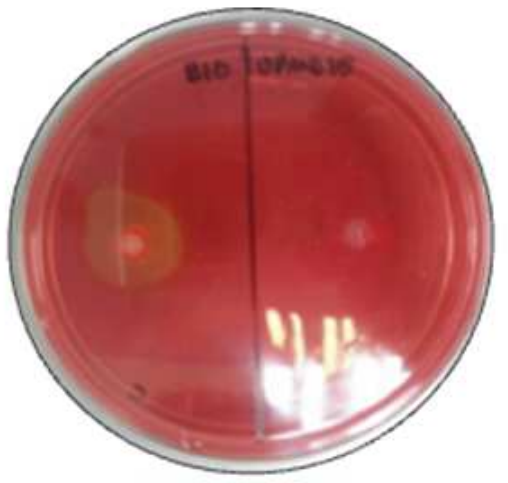

(b)

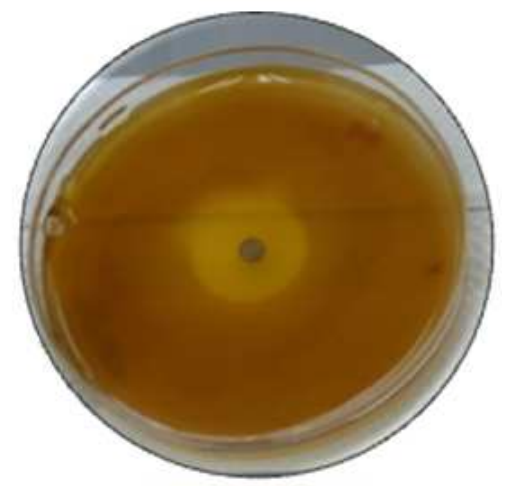

(c)

Fig. 7. Chrome Azurol S (a) cellulose (b) pectinase (c) agar plates after inoculation with selected isolates Note: Positive results areindicated by the formation of halo zonearound the colonies

Table 6. Assessment of siderophore and hydrolyzing enzyme production of selected isolates

\begin{tabular}{llll}
\hline Strain & Siderophore production & Cellulase production & Pectinase production \\
\hline UPMB19 & ++ & ++ & - \\
UPMB20 & ++ & + & - \\
UPMR30 & + & - & - \\
UPMR31 & + & - & - \\
UPMB10 & + & +++ & +++ \\
\hline
\end{tabular}

Note: $+=$ Positive; - = Negative

Table 7. Bacterial identification using 16S rDNA gene amplification

\begin{tabular}{|c|c|c|c|c|}
\hline \multirow[b]{2}{*}{ Isolates } & \multicolumn{4}{|l|}{ Molecular Identification } \\
\hline & 16S rDNA fragment length (bp) & Closest relatives in NCBI & NCBI accession number & Similarity $(\%)$ \\
\hline UPMB10 & 1451 & $\begin{array}{l}\text { Bacillus subtilis } \\
\text { strain Ljb-4 }\end{array}$ & KF649246.1 & 97 \\
\hline UPMB19 & 1441 & $\begin{array}{l}\text { Lysinibacillus xylanilyticus } \\
\text { strain GDLY1 }\end{array}$ & JN999887.1 & 94 \\
\hline UPMB20 & 1443 & $\begin{array}{l}\text { Alcaligenes faecalis } \\
\text { strain B17 }\end{array}$ & KF641851.1 & 97 \\
\hline UPMR30 & 1486 & $\begin{array}{l}\text { Bradyrhizobium japonicum } \\
\text { strain HHB-02 }\end{array}$ & DQ517954.1 & 99 \\
\hline UPMR31 & 1429 & $\begin{array}{l}\text { Rhizobium etli bv. mimosae } \\
\text { strain Mim-1 }\end{array}$ & DQ648573.1 & 99 \\
\hline
\end{tabular}

The selected bacterial isolates were identified via sequencing of its 16s rDNA gene. As shown in Table 7, BLAST searches against the NCBI nucleotide database revealed close relationship to known plant-associated bacteria, including genera Bacillus, Lysinibacillus, Alcaligenes, Bradyrhizobium and Rhizobium.

These five selected isolates were then used in plant inoculation studies in plant growth chambers under sterile condition. The rice seedlings were inoculated during transplanting at the rate of $2 \mathrm{~mL} / \mathrm{seedling}$. At
14 Days After Transplanting (DAT), plants were harvested and various parameters including plant height and Total Dry Weight (TDW) and bacterial population and IAA production in the residual nutrient solution were taken.

Inoculation with UPMB10 and UPMR31 produced significantly taller rice seedlings at $17.15 \mathrm{~cm}$ and 17.5 $\mathrm{cm}$ and heavier total dry weight at $74.7 \mathrm{mg}$ and 74.65 $\mathrm{mg}$, respectively, at 14 DAT (Fig. 8 and 9). All other inocula also resulted in significantly taller rice seedlings at 7 and 14 DAT and total dry weight 
without fertilizer-N application. UPMB19 treatment produced the tallest riceseedlings at 7 DAT but not towards the end of the experiment.

Results on survival of bacteria in residual plant nutrient solution showed that UPMB10 and UPMR31 isolates survived better in the residual nutrient solution by maintaining their population at $5.9 \times 10^{8}$ and $6.6 \times 10^{8}$ CFU $\mathrm{mL}^{-1}$, respectively (Fig. 10). In the current study, the addition of $33 \%$ fertilizer- $\mathrm{N}$ lowered the bacterial population in all treatments except for UPMB19 while UPMB10 maintained the significantly high population at $2.6 \times 10^{8} \mathrm{CFU} \mathrm{mL}^{-1}$.

At 7 DAT, UPMB10, UPMB20 and UPMR30 significantly increased the IAA production to 0.678 , 0.592 and $0.603 \mu \mathrm{g} \mathrm{mL} \mathrm{m}^{-1}$, respectively (Fig. 11). UPMB10 maintained a significantly higher IAA, $0.774 \mu \mathrm{g} \mathrm{mL}^{-1}$, at $14 \mathrm{DAT}$. A similar result was also observed for treatment with UPMR31, $0.773 \mu \mathrm{g} \mathrm{mL}{ }^{-1}$.

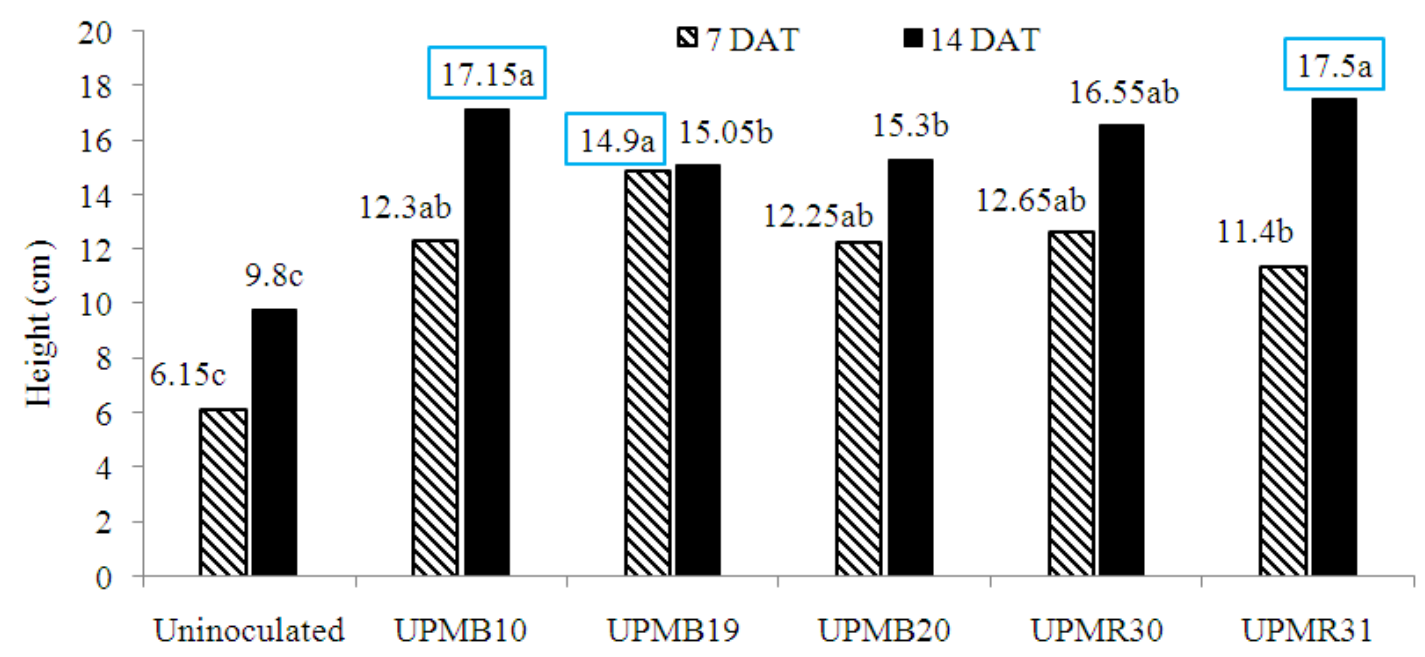

Fig. 8. Effects of rhizobial and PGPR inoculation (with no fertilizer-N) on height of seedlings at 7 and 14 DAT Note: Different letters within each column are significantly different at 0.05 level

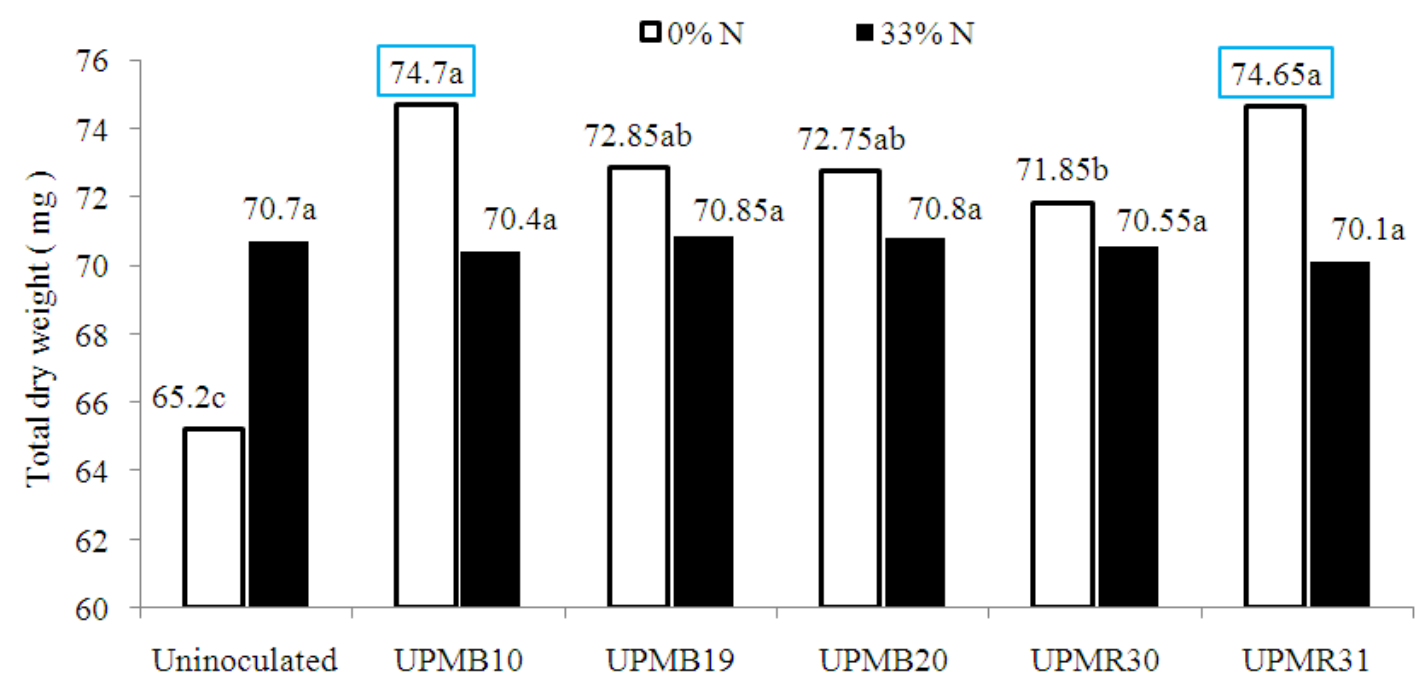

Fig. 9. Effects of rhizobial and PGPR inoculations on TDW of seedlings provided with 0 and $33 \%$ fertilizer-N(14 DAT) Note: Different letters within each column are significantly different at 0.05 level 


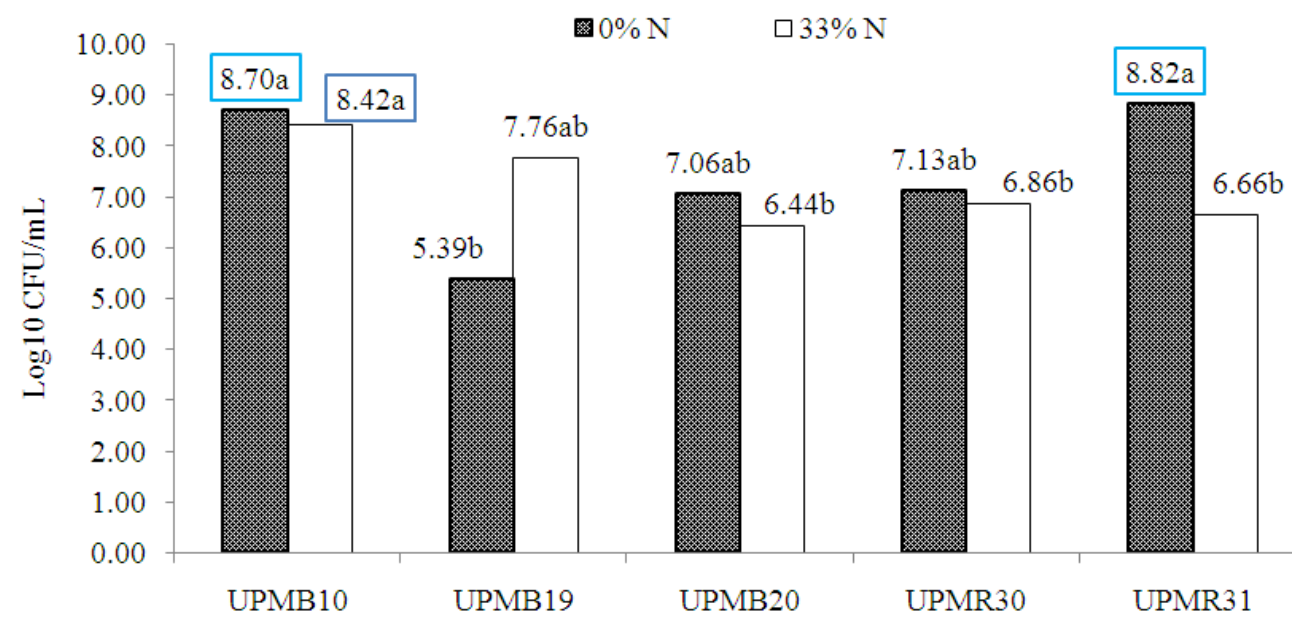

Fig. 10. Total bacterial population in residual plant nutrient solution provided with $0 \%$ and $33 \%$ fertilizer-N at 7 DAT Note: Different letters within each column are significantly different at 0.05 level

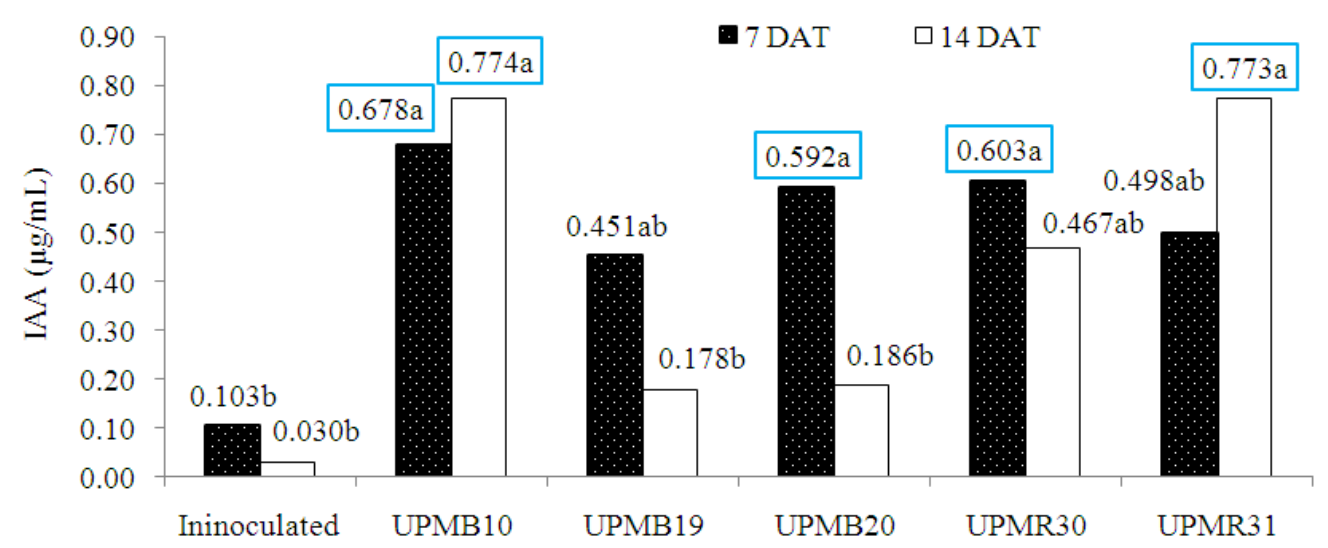

Fig. 11. Effects of different isolates on Indole-3-acetic acid production at 7 and 14 DAT with $0 \%$ fertilizer-N addition Note: Different letters within each column are significantly different at 0.05 level

\section{DISCUSSIONS}

Several locations were chosen to observe biodiversity of bacterial isolates due to different cultural agronomic practices and geographical distribution. It is hypothesized that there would be greater chances of beneficial bacterial interactions with plant roots from locations which practice minimal and chemical-free planting systems, namely in Terengganu, Kedah and Kelantan. Isolation at Sik, Kedah represented a major rice growing state located on the north-west coast of Peninsular Malaysia. Rice fields at Tunjung, Kelantan and Sik, Kedah practiced the System of Rice Intensification (SRI) which is a chemical-free system. Bacterial isolation at these locations are vital due to the higher chances of bacterial interactions with the rice plant roots. PGPR and rhizobia play more important roles especially in supplying nutrients to the plants in a less fertilized soil. Adesemoye and Kloepper (2009) reported an equivalent plant growth, yield and nutrient uptake of tomato when supplied with $75 \%$ of recommended fertilizer with addition of microorganism inoculants, compared to fully fertilized plants. ${ }^{15} \mathrm{~N}$ studies in 2012 have revealed that UPMB10 (Bacillus $s p$.) fixed $67 \%$ of nitrogen in the young oil palm through biological $\mathrm{N}_{2}$ fixation (Zakry et al., 2012). It seems like the PGPR isolates at sites with long history of rice cultivation have developed a survival mechanism against harsh rhizospheric environment by acquiring an ability to penetrate the cell wall and reside within the root tissues 
as endophytes. One of the probable mechanism is through production of hydrolyzing enzymes namely cellulase and pectinase, as suggested by Reinhold-Hurek and Hurek (1998). Besut produced the highest number of PGPR isolation and this was anticipated since the rice farmers at Besut practised minimal chemical fertilizer system, which increased bacterial interactions with plant roots. Nutrients were supplied to the plant through conventional system at UPM, thus lesser bacterial population was found. Meanwhile, organic farming areas in Kedah and Kelantan which did not apply chemical fertilizers would not have the starter plant nutrients for the bacteria to interact initially with the plant roots for plant growth promotion. This hypothesis was supported by Anderson and Peterson (1978) who suggested the importance of starter fertilizer in sugar beet when there was limited root growth due to nutrient deficiencies. The soil microbes also required minimal supply of nitrogen as starter- $\mathrm{N}$ to grow and establish to produce beneficial effects on oil palm seedlings (Ai'shah et al., 2010). Nevertheless, the numbers of PGPR isolated from each location were almost similar with findings by Jha and Subramaniam (2012), Panhwar et al. (2012) and Bhromsiri and Bhromsiri (2010) who had collected 35, 43 and 68 bacterial strains, respectively, from various locations of rice field.

$\mathrm{N}_{2}$-fixation ability was the first screening criteria of the isolates since this characteristic is vital and crucial to the plants as a potential alternative to reduce chemical Nfertilizer application. Bacterial strains with dual beneficial characteristics isolated from this study are slightly higher than isolation percentage of $\mathrm{N}_{2}$-fixing bacteria from Korean rice fields (Islam et al., 2012), 32 out of $165(19.4 \%)$ and lower than isolation of diazotrophs from pepper vine (Zakry et al., 2010, 14 out of $45(31.1 \%)$. Diazotrophs contain nitrogenase enzyme and thus capable of fixing atmospheric nitrogen into ammonium which are subsequently absorbed by plants via Biological $\mathrm{N}_{2}$ Fixation (BNF) process (Boddey et al., 1995). It has been reported by Vargas et al. (2012) that rice seedlings can obtain variable contributions from BNF namely increased lateral root development and ethylene signalling responses upon inoculation with diazotrophic bacteria such as Azospirillum brasilense sp245 and Bukholderia kururiensis M130.

The IAA production by bacterial isolates in this study were almost similar with selected isolates of Azotobacter, fluorescent Pseudomonas and Bacillus from rhizospheric soils of different crops namely mustard, barseem, wheat, sugarcane, brinjal, onion, cauliflower, cabbage and root nodules of chick pea (Ahmad et al., 2008); Corynebacterium agropyri, Enterobacter gergoviae and Bacillus amyloliquefaciens ( $\mathrm{Ng}$ et al., 2012) and from rice soil diazotrophic isolates (Naher et al., 2009) which ranged from 7.03-22.02, 3.56-24.32 and 32-69 $\mu \mathrm{g} \mathrm{mL}^{-1}$ respectively, when using the same concentration of tryptophan as the precursor ( $1 \mathrm{~mL} / 20 \mathrm{~mL}$ broth). IAA production is believed to be crucial for promotion of root elongation and root hair development. Biswas et al. (2000) suggested a probable connection between increased tiller production and yield of rice with a change in hormonal balance, particularly IAA, due to rhizobial inoculation. Duangpaeng et al. (2012) conducted the same method as in the current study by selecting endophytic bacteria based on their IAA production and showed that several high IAA-producing bacteria increased shoot and root length of rice, while producing the highest number of shoots per plant and shoot height in paper germination on Petri dish and in pot experiments.

The Acetylene Reduction Assay (ARA) is an indirect method to quantify Biological $\mathrm{N}_{2}$ Fixation (BNF) rate since it measures the conversion of acetylene to ethylene by the nitrogenase enzymes, similar to the reduction of $\mathrm{N}_{2}$ to $\mathrm{NH}_{3}$ in $\mathrm{BNF}$ by diazotrophs. The ethylene produced by these bacterial strains were much higher than those recorded by Katupitiya et al. (1995) with Azospirillum (Sp7) inoculation which produced only $2.3 \mathrm{nmol}$ $\mathrm{C}_{2} \mathrm{H}_{4}$ /plant/hour. This is also true when compared with diazotroph isolates from rice by Naher et al. (2009) which ranges from $6.1 \times 10^{-8}$ to $1.2 \times 10^{-3} \mathrm{nmol} \mathrm{C}_{2} \mathrm{H}_{4} / \mathrm{cfu} / \mathrm{hr}$. The selection of these bacterial strains in the current study was crucial for the next plant inoculation test to minimize inorganic fertilizer-N usage while still benefitting other positive effects of the plant-bacterial interactions.

Meanwhile, phosphate solubilization index value for UPMB10 and UPMB20 showed a gradual increased from D2 to D10 which suggested that these bacterial strains could still solubilize more insoluble phosphate even after 10 days of incubation period. Thus, these two PGPR strains could be more beneficial to plants, since the insoluble phosphate solubilization process occurs in the soil for a longer period. Phosphate solubilization occurs when the microbes release metabolites such as organic acids (Ramachandran et al., 2005; Panhwar et al., 2012) which will reduce the media $\mathrm{pH}$ and consequently solubilize the insoluble tricalcium phosphate, $\mathrm{Ca}_{3}\left(\mathrm{PO}_{4}\right)_{2}$. This criterium is vitally important in the preliminary screening for potential biofertilizer inoculum, especially to minimize the excessive inputs of inorganic phosphate fertilizers in soil environment, as earlier suggested by 
Sitepu et al. (2007). This criterium was also assessed by Afzal and Asghari (2008) whereby inoculation with Phosphate Solubilizing Bacteria (PSB) along with 30$40 \%$ of $\mathrm{P}$ fertilizer resulted in improved grain yield of wheat compared to sole application of $\mathrm{P}$ fertilizer without PSB. There are reports of contradictory results between halo zone plate detection and $\mathrm{P}$ solubilization in liquid culture (Rashid et al., 2004). Nautiyal (1999) has shown that phosphate solubilization test based on NBRIP broth assay has higher efficiency up to 3 -fold. Inorganic phosphate solubilization was directly related to the decline in $\mathrm{pH}$ (Asea et al., 1988) and this has been reported to be due to the production of organic acids and acid phosphatases by the microbes (Perez et al., 2007; Rodriguez and Fraga, 1999). Similar findings were found in this study which further supports the previous reports. Meanwhile, a group of researchers from China have also shown that $\mathrm{P}$ released from insoluble form of phosphate was negatively correlated to the solution $\mathrm{pH}$ (Liu et al., 2012). Several strains of Rhizobium were also reported to be able to solubilize insoluble phosphate compound, hydroxyapatite and the mechanism involved was the production of 2ketogluconic acid by the rhizobial strains (Halder and Chakrabartty, 1993).

Potassium solubilization rates for these bacterial strains were higher than Bacillus mucilaginous MCRCp1 which was reported to solubilize $\mathrm{K}$ at the rate of $4.29 \mu \mathrm{g}$ $\mathrm{mL}^{-1}$ after 4 days of incubation (Sugumaran and Janarthanam, 2007). The bacteria might produce acids, alkalis or chelants which enhance the release of elements from potassium bearing minerals such as muscovite mica.

Siderophore production test using CAS agar plate is useful for rapid screening of potential beneficial bacterial isolates; bacteria with the ability to produce siderophore can enhance plant growth by increasing the availability of iron near the roots for plant uptake (Alexander and Zuberer, 1991). Several reports have claimed that hydrolyzing enzyme production, particularly cellulase and pectinase, could be the mode of entry for the bacteria into the roots and act as endophytes. This is because cell wall is mainly composed of cellulose while the middle lamella between cell walls contains mainly pectin. However, this probability has not been fully studied in diazotrophic endophytes (Reinhold-Hurek and Hurek, 1998), thus the significance of this study. Strain UPMB20 is an endophyte, while strain UPMB19 was isolated from rice root rhizosphere. Previous study using Scanning Electron Microscopy (SEM) has shown that UPMB10 has the ability to act as an endophyte by colonizing the root interiors of rice plant (Premalatha, 2006). Hence, there is a probability that strain UPMB 19 could also become endophytic with its cellulase production. Vessey (2003) also had earlier stated in a review that PGPR which have cellulase and pectinase activities could certainly aid in the infection process by gaining entry into the root system.

Based on 16S rDNA gene sequencing, UPMB19, UPMB20, UPMR30, UPMR31 and UPMB10 were identified under several genera: Lysinibacillus, Alcaligenes, Bradyrhizobium, Rhizobium and Bacillus, respectively. Bacillus subtilis has been explored as a great biocontrol agent in various crops by acting as an elicitor of plant induced systemic resistance (ISR) to pests and pathogens (Kloepper et al., 2004; Lugtenberg and Kamilova, 2009; Lucy et al., 2004). Lysinibacillus xylanilyticus was isolated by other researchers from a compost of fruit and vegetable waste and shown to be able to solubilize tri-calcium phosphate, produce phytohormone (IAA), carried nif $H$ gene for BNF activities and successfully improved growth of wheat (Triticum aestivum) under controlled conditions (Hayat et al., 2013). Alcaligenes faecalis has been shown to secrete IAA as plant growth-promoter in young lettuce seedling (Barazani and Friedman, 1999), while others have classified this strain as a salt-tolerant bacteria and a potential human pathogen (Egamberdieva et al., 2008). Bradyrhizobium and Rhizobium are two well-known bacteria in legume symbiosis, with vital roles on nodule formation and BNF (Nguyen et al., 2012; Suzuki et al., 2014; Klonowska et al., 2012).

Results from the plant inoculation test showed that isolates from different crops are able to increase the growth of rice plants (taller and heavier) since UPMB10 was isolated from oil palm and UPMR31 was from Mimosa pudica. UPMB19 produced tallest seedlings in the early observation but not towards the latter stage, indicating that this strain has the ability to promote seedling growth as early as 7 DAT, while UPMB10 and UPMR 31 performed better at 14 DAT. The beneficial effects of bacterial inoculation were possibly derived through biological $\mathrm{N}_{2}$ fixation particularly when no fertilizer-N was provided. Treatment with UPMB19 also showed significantly higher $\mathrm{N}_{2}$ fixation rate compared to the other strains except UPMB20 (Fig. 1). A greater rhizobial inoculation effects on plant photosynthesis rate has been reported with zero-N treatment, compared to treatment with $90 \mathrm{~kg} \mathrm{~N} \mathrm{Ha}^{-1}$ (Peng et al., 2002). Yanni et al. (1997) also stated that two endophytic isolates of Rhizobium leguminosarum bv. trifolii 
significantly increased shoot and root growth of rice in plant growth chamber experiment. This early growth promotion effects on rice seedlings has also been observed by Vargas et al. (2012) upon inoculation with diazotrophic bacteria which promoted lateral root development. Ashrafuzzaman et al. (2009) reported a significant increase in plant height, root length and dry matter production of shoot and root of rice seedling in a pot experiment. Isolates UPMB10 and UPMR30 maintained a significantly higher bacterial population possibly due to their abilities to actively interact with the rice roots when provided with zero amount of fertilizerN. Similarly, Chi et al. (2005) and James et al. (2002) observed high endophytic rhizobial population in rice which reached $9 \times 10^{10}$ rhizobia per $\mathrm{cm}^{3}$ tissues and $10^{6}$ CFU per gram of fresh weight, respectively. The increased population of UPMB19 with increased fertilizer-N supply indicates that this PGPR favours condition with minimal inorganic- $\mathrm{N}$ for a population increment of $44 \%$ compared to the treatment with zero fertilizer-N. The importance of minimal fertilizer-N as a starter nutrient for plants and bacteria to grow and interact beneficially has been well-demonstrated by other researchers (Becker et al., 1991; Mia et al., 2010a). This could have led to the increase in plant height and total dry weight observed in UPMB10 and UPMR31 inoculations. The significantly higher IAA productions by UPMB10 and UPMR31 were believed to have caused greater root development and consequently increased plant height and TDW (Fig. 6 and 7) as also observed by Patten and Glick (2002). In their case, inoculation with bacterial isolates which produced IAA caused longer primary roots of canola and more numerous adventitious roots in mung bean cuttings. PGPR and rhizobia have been suggested to stimulate growth of rice seedlings by producing phytohormones, particularly IAA, which promote seed emergence and other seedling attributes (Mia et al., 2012; Keyeo et al., 2011). Battacharjee et al. (2012) also found that rhizobial strain namely Rhizobium leguminosarum could secrete phytohormones such as IAA and increase the biomass, root branching and $\mathrm{N}$ content of rice plants.

\section{CONCLUSION}

From the current study, inoculation of rice plant with three Plant Growth-Promoting Rhizobacteria (PGPR) and two indigenous rhizobial isolates from tropical Malaysian soils promoted plant growth which could be directly attributed to the beneficial effects from biological $\mathrm{N}_{2}$ fixation and phytohormone production and indirectly to phosphate and potassium solubilizations, iron siderophore and hydrolyzing enzyme productions. These strains belong to genera Bacillus, Lysinibacillus, Alcaligenes, Bradyrhizobium and Rhizobium, respectively. Hence, these findings could be useful and crucial for the preliminary biofertilizer development for rice and other non-legume crops in Malaysia and the tropics. These initial findings are useful as a fundamental information on the effects of local beneficial strains on early plant growth, thus a subsequent glasshouse and field trials need to be undertaken to elucidate the contributions of these PGPR and rhizobia on tillering and yield of rice with reduced fertilizer-N rates.

\section{ACKNOWLEDGEMENT}

This study was supported by grants from Long-term Research Grant Scheme (LRGS) no. 5525019 under the Ministry Of Education (MOE) and ScienceFund no. 0201-04-SF1190 under the Ministry Of Science, Technology and Innovation (MOSTI), Malaysia. The senior author was also sponsored by MOSTI under theNational Science Fellowship (NSF) scheme.

\section{REFERENCES}

Adesemoye, A.O. and J.W. Kloepper, 2009. Plantmicrobes interactions in enhanced fertilizer-use efficiency. Applied Microbiol. Biotechnol., 85: 112. DOI: $10.1007 / \mathrm{s} 00248-009-9531-y$

Afzal, A. and B. Asghari, 2008. Rhizobium and phosphate solubilizing bacteria improve the yield and phosphorus uptake in wheat (Triticum aestivum L.). Int. J. Agri. Biol., 10: 1560-8530. Ahmad, F., I. Ahmad and M.S. Khan, 2008. Screening of freeliving rhizospheric bacteria for their multiple plant growth promoting activities. Microbiol. Res., 163: 173-181. DOI: 10.1016/j.micres.2006.04.001

Ai'shah, O.N., H.G. Amir, C.L. Keng and A.R. Othman, 2010. Influence of various combinations of diazotrophs and chemical $\mathrm{N}$ fertilizer on plant growth and nitrogen fixation capacity of oil palm seedlings (Elaeis guineensis Jacq.). Thai J. Agric. Sci., 43: 139-149.

Alexander, D.B. and D.A. Zuberer, 1991. Use of chrome azurol $S$ reagents to evaluate siderophore production by rhizosphere bacteria. Biol. Fertil. Soil., 12: 39-45. DOI: $10.1007 / \mathrm{BF} 00369386$ 
Amir, H.G., Z.H. Shamsuddin, M.S. Halimi, M.F. Ramlan and M. Marziah, 1999. Potential use of rhizobacteria for sustainable oil palm seedling production. Malaysian J. Soil. Sci., 3: 39-50.

Amir, H.G., Z.H. Shamsuddin, M.S. Halimi, M.F. Ramlan and M. Marziah, 2003. Nitrogen fixation, nutrient accumulation and plant growth promotion by rhizobacteria in association with oil palm seedlings. Pak. J. Biol. Sci., 6: 1269-1272.

Amir, H.G., Z.H. Shamsuddin, M.S. Halimi, M.F. Ramlan and M. Marziah, 2005. Enhancement in nutrient accumulation and growth of oil palm seedlings caused by PGPR under field nursery conditions. Commun. Soil Sci. Plant Anal., 36: 2059-2066. DOI: 10.1080/00103620500194270

Anderson, F.N. and G.A. Peterson, 1978. Optimum starter fertilizer placement for sugarbeet seedlings as determined by uptake of radioactive ${ }^{32} \mathrm{P}$ isotope. J. Am. Society Sugar Beet Technol., 20: 19-24.

Araujo, A.E.D.S., V.L.D. Baldani, P.D.S. Galisa, J.A. Pereira and J.I. Baldani, 2013. Response of traditional upland rice varieties to inoculation with selected diazotrophic bacteria isolated from rice cropped at the Northeast region of Brazil. Applied Soil. Ecol., 64: 49-55. DOI: 10.1016/j.apsoil.2012.10.004

Asea, P.E.A., R.M.N. Kucey and J.W.B. Stewart, 1988. Inorganic phosphate solubilization by two Penicillium species in solution culture and soil. Soil Biol. Biochem., 20: 459-464. DOI: 10.1016/00380717(88)90058-2

Ashrafuzzaman, M., F.A. Hossen, M.R. Ismail, M.A. Hoque and M.Z. Islam et al., 2009. Efficiency of Plant Growth-Promoting Rhizobacteria (PGPR) for the enhancement of rice growth. African J. Biotechnol., 8: 1247-1252.

Barazani, O.Z. and J. Friedman, 1999. Is IAA the major root growth factor secreted from plant-growthmediating bacteria? J. Chemical Ecol., 10: 23972406. DOI: 10.1023/A:1020890311499

Barton, C.J., 1948. Photometric analysis of phosphate rock. Anal. Chem., 20: 1068-1073. DOI: 10.1021/ac60023a024

Battacharjee, R.B., P. Jourand, C. Chaintreuil, B. Dreyfus, A. Singh and S.N. Mukhopadhyay, 2012. Indole acetic acid and ACC deaminase -producing Rhizobium leguminosarum bv. trifolii SN10 promote rice growth and in the process undergo colonization and chemotaxis. Biol. Fert. Soils, 48: 173-182. DOI: 10.1007/s00374-011-0614-9
Becker, M., K.H. Diekmann, J.K. Ladha, S.K.D. Datta and J.C.G. Ottow, 1991. Effect of NPK on growth and nitrogen fixation of Sesbania rostrata as a green manure for lowland rice (Oryza sativa L.). Plant Soil, 132: 149-158. DOI: 10.1007/BF00011021

Bhromsiri, C. and Bhromsiri, 2010. Isolation, screening of growth-promoting activities and diversity of rhizobacteria from vetiver grass and rice plants. Thai J. Agric. Sci., 43: 217-230.

Biswas, J.C., J.K. Ladha and F.B. Dazzo, 2000. Rhizobia inoculation improves nutrient uptake and growth of lowland rice. Soil Sci. Society Am. J., 64: 16441650. DOI: $10.2136 /$ sssaj2000.6451644x

Boddey, R.M., J.C.D.S. Moraes, B.J.R. Alves and S. Urquiaga, 1997. The contribution of biological nitrogen fixation for sustainable agricultural systems in the tropics. Soil Biol. Biochem., 29: 787-799. DOI: 10.1016/S0038-0717(96)00221-0

Boddey, R.M., O.C.D. Oliveira, S. Urquiga, V.M. Reis and F.L.D. Olivares et al., 1995. Biological nitrogen fixation associated with sugar cane and rice: Contributions and prospects for improvement. Plant Soil, 174: 195-209. DOI: 10.1007/BF00032247

Chabot, R., H. Antoun and M.P. Cescas, 1996. Growth promotion of maize and lettuce by phosphatesolubilizing Rhizobium leguminosarum biovar. phaseoli. Plant Soil, 184: 311-321. DOI: 10.1007/BF00010460

Chi, F., S.H. Shen, H.P. Cheng, Y.X. Jing and Y.G. Yanni et al., 2005. Ascending migration of endophytic rhizobia, from roots to leaves, inside rice plants and assessment of benefits to rice growth physiology. Applied Environ. Microbiol., 71: 72717278. DOI: 10.1128/AEM.71.11.7271-7278.2005

Dobereiner, J. and J.M. Day, 1975. Associative symbiosis in tropical grasses: Characterization of microorganisms and dinitrogen fixing sites. Proceedings of the 1st International Symposium on Nitrogen Fixation, (SNF' 75), Washington State University Press, Pullman, pp: 518-538.

Duangpaeng, A., P. Phetcharat, S. Chanthapho, N. Boonkantong and N. Okuda, 2012. The study and development of endophytic bacteria for enhancing organic rice growth. Procedia Eng., 32:172-176. DOI: 10.1016/j.proeng.2012.01.1253

Egamberdieva, D., F. Kamilova, S. Validov, L. Gafurova and Z. Kucharova et al., 2008. High incidence of plant growth-stimulating bacteria associated with the rhizosphere of wheat grown on salinated soil in Uzbekistan. Environ. Microbiol., 10: 1-9. DOI: 10.1111/j.1462-2920.2007.01424.x 
Egener, T., T. Hurek and B. Reinhold-Hurek, 1999. Endophytic expression of nif genes of Azoarcus sp. strain BH72 in rice roots. Molecular Plant-Microbe Interact. $\quad$ 12: 813-819. DOI: 10.1094/MPMI.1999.12.9.813

FAO., 2004. Food and Agriculture Organization. Rice is Life. Italy: FAO.

Farzana, Y., O. Radziah, S. Kamaruzaman and S.S. Mohd, 2007. Effect of PGPR inoculation on growth and yield of sweet potato. J. Biol. Sci., 7: 421-424. DOI: $10.3923 /$ jbs.2007.421.424

Farzana, Y., O. Radziah, S. Said and S. Kamaruzaman 2009. Growth and storage root development of sweetpotato inoculated with rhizobacteria under glasshouse conditions. Australian J. Basic Applied Sci., 3: 1461-1466.

Gordon, S.A. and R.P. Weber, 1951. Colorimetric estimation of indoleacetic acid. Plant Physiol., 26: 192-195. DOI: 10.1104/pp.26.1.192

Halder, A.K. and P.K. Chakrabartty, 1993. Solubilization of inorganic phosphate by Rhizobium. Folia Microbiol., 38: 325-330. DOI: 10.1007/BF02898602

Hardy, R.W.F., R.D. Holsten, E.K. Jackson and R.C. Burns, 1968. The acetylene-ethylene assay for nitrogen fixation: Laboratory and field evaluation. Plant Physiol., 43: 1185-1207. DOI: 10.1104/pp.43. 8.1185

Hayat, R., R.A. Sheirdil, M. Iftikar-ul-Hassan and I. Ahmed, 2013. Characterization and identification of compost bacteria based on 16S rRNA gene sequencing. Ann. Microbiol., 63: 905-912. DOI: 10.1007/s13213-012-0542-4

$\mathrm{Hu}$, X., J. Chen and J. Guo, 2006. Two phosphate- and potassium solubilizing bacteria isolated from Tianmu Mountain, Zhejiang, China. World J. Microbiol. Biotechnol., 22: 983-990. DOI: 10.1007/s11274-006-9144-2

Islam, M.R., T. Sultana, J. Cho, M.M. Joe and T.M. Sa, 2012. Diversity of free-living nitrogen-fixing bacteria associated with Korean paddy fields. Ann. Microbiol., 62: 1643-1650. DOI: 10.1007/s13213012-0421-z

James, E.K., P. Gyaneshwar, N. Mathan, W.L. Barraquio and P.M. Reddy et al., 2002. Infection and colonization of rice seedlings by the plant growthpromoting bacterium Herbaspirillum seropedicae z67. Molecular Plant-Microbe Interact., 15: 894906. DOI: 10.1094/MPMI.2002.15.9.894

Jha, Y. and R.B. Subramaniam, 2012. Isolation of root associated bacteria from the local variety of rice GJ17. World Res. J. Geo Inform., 1: 21-26.
Kasana, R.C., R. Salwan, H. Dhar, S. Dutt and A. Gulati, 2008. A rapid and easy method for the detection of microbial cellulases on agar plates using Gram's iodine. Current Microbiol., 57: 503-507. DOI: 10.1007/s00284-008-9276-8

Katupitiya, S., J. Millet, M. Vesk, L. Viccars and A. Zeman et al., 1995. A mutant of Azospirillum brasilense $\mathrm{Sp} 7$ impaired in flocculation with a modified colonization pattern and superior nitrogen fixation in association with wheat. Applied Environ. Microbiol., 61: 1987-1995. PMID: 7646034

Kennedy, I.R., A.T.M.A. Choudhury and M.L. Kecskes, 2004. Non-symbiotic bacterial diazotrophs in cropfarming systems: Can their potential for plant growth promotion be better exploited? Soil Biol. Biochem., 36: 1229-1244. DOI: 10.1016/j.soilbio.2004.04.006

Keyeo, F., O.N. Ai'shah and H.G. Amir, 2011. The effects of nitrogen fixation activity and phytohormone production of diazotroph in promoting growth of rice seedlings. Biotechnology, 10: 267-273. DOI: 10.3923/biotech.2011.267.273

Kloepper, J.W., C. Ryu and S. Zhang, 2004. Induced systemic resistance and promotion of plant growth by Bacillus spp. Phytopathology, 94: 1259-1266. DOI: 10.1094/PHYTO.2004.94.11.1259, PMID: 18944464

Kloepper, J.W., J. Leong, M. Teintze and M.N. Schroth, 1980. Enhanced plant growth by siderophores produced by plant growth-promoting rhizobacteria. Nature, 286: 885-886. DOI: 10.1038/286885a0

Klonowska, A., C. Chaintreuil, P. Tisseyre, L. Miche, R. Melkonian and M. Ducousso et al., 2012. Biodiversity of Mimosa pudica rhizobial symbionts (Cupriavidus taiwanensis, Rhizobium mesoamericanum) in New Caledonia and their adaptation to heavy metal-rich soils. Microbiol. Ecol., 81: 618-635. DOI: 10.1111/j.15746941.2012.01393.x

Kumar, K.V., S. Srivastava, N. Singh and H.M. Behl, 2009. Role of metal resistant plant growth promoting bacteria in ameliorating fly ash to the growth of Brassica juncea. J. Hazardous Materials, 170: 51-57. DOI: 10.1016/j.jhazmat.2009.04.132

Liu, Y., L. Feng, H. Hu, G. Jiang and Z. Cai et al., 2012. Phosphorus release from low-grade phosphate rocks by low molecular weight organic acids. J. Food, Agric. Environ., 10: 1001-1007.

Lucy, M., E. Reed and B.R. Glick, 2004. Applications of free living plant growth-promoting rhizobacteria. Antonie Van Leeuwenhoek, 86: 1-25. DOI: 10.1023/B:ANTO.0000024903.10757.6e 
Lugtenberg, B. and F. Kamilova, 2009. Plant-growthpromoting rhizobacteria. Annual Rev. Microbiol., 63: 541-556.

DOI: 10.1146/annurev.micro.62.081307.162918

Malik, K.A., R. Bilal, S. Mehnaz, G. Rasul and M.S. Mirza et al., 1997. Association of nitrogen-fixing, Plant-Growth-Promoting Rhizobacteria (PGPR) with kallar grass and rice. Plant Soil, 194: 37-44. DOI: 10.1023/A:1004295714181

Mia, M.A.B., Z.H. Shamsuddin and M. Mahmood, 2012. Effects of rhizobia and plant growth promoting bacteria inoculation on germination and seedling vigor of lowland rice. African J. Biotechnol., 11: 3758-3765. DOI: 10.5897/AJB09.1337

Mia, M.A.B., Z.H. Shamsuddin, Z. Wahab and M. Marziah 2010a. Rhizobacteria as bioenhancer and biofertilizer for growth and yield of banana (Musa spp. cv. 'Berangan'). Scientia Horticulturae, 126: 80-87. DOI: 10.1016/j.scienta.2010.06.005

Mia, M.A.B., Z.H. Shamsuddin, Z. Wahab and M. Marziah, 2009. The effect of rhizobacterial inoculation on growth and nutrient accumulation of tissue-cultured banana plantlets under low Nfertilizer regime. African J. Biotechnol., 8: 58555866.

Mia, M.A.B., Z.H. Shamsuddin, Z. Wahab and M. Marziah, 2010b. Effect of Plant Growth Promoting Rhizobacterial (PGPR) inoculation on growth and nitrogen incorporation of tissue-cultured Musa plantlets under nitrogen-free hydroponics condition. Aus. J. Crop Sci., 4: 85-90.

Naher, U.A., O. Radziah, Z.H. Shamsuddin, M.S. Halimi and I.M. Razi, 2009. Isolation of diazotrophs from different soils of Tanjong Karang rice growing area in Malaysia. Int. J. Agric. Biol., 11: 547-552.

Nautiyal, C.S., 1999. An efficient microbiological growth medium for screening phosphate solubilizing microorganisms. FEMS Microbiol. Lett., 170: 265270. DOI: 10.1111/j.1574-6968.1999.tb13383.x

Ng, L.C., M. Sariah, O. Sariam, O. Radziah and M.A.Z. Abidin, 2012. Rice seed bacterization for promoting germination and seedling growth under aerobic cultivation system. Australian J. Crop Sci., 6: 170-175.

Nguyen, T.H.N., L. Brechenmacher, J.T. Aldrich, T.R. Clauss and M.A. Gritsenko et al., 2012. Quantitative phosphoproteomic analysis of soybean root hairs inoculated with bradyrhizobium japonicum. Molecular Cellular Proteom., 11: 1140-1155. DOI: 10.1074/mcp.M112.018028
Panhwar, Q.A., O. Radziah, A.R. Zaharah, M. Sariah and I.M. Razi, 2012. Isolation and characterization of phosphate-solubilizing bacteria from aerobic rice. African J. Biotech., 11: 2711-2719. DOI: 10.5897/AJB10.2218

Patten, C.L. and B.R. Glick, 2002. Role of Pseudomonas putida indoleaccetic acid in development of the host plant root system. Applied Environ. Microbiol., 68: 3795-3801. DOI: 10.1128/AEM.68.8.37953801.2002

Peng, S., J.C. Biswas, J.K. Ladha, P. Gyaneshwar and Y. Chen, 2002. Influence of rhizobial inoculation on photosynthesis and grain yield of rice. Agron. J., 94: 925-929. DOI: 10.2134/agronj2002.9250

Perez, E., M. Sulbaran, M.M. Ball and L.A. Yarzabal, 2007. Isolation and characterization of mineral phosphate-solubilizing bacteria naturally colonizing a limonitic crust in the south-eastern Venezuelan region. Soil Biol. Biochem., 39: 2905-2914. DOI: 10.1016/j.soilbio.2007.06.017

Pikovskaya, R.I., 1948. Mobilization of phosphorus in soil in connection with vital activity by some microbial species. Microbiologica, 17: 362-370.

Premalatha, P., 2006. Colonization of oryza sativa roots by plant growth-promoting rhizobacterium, Bacillus sphaericus UPMB10 and subsequent inoculant formulation. PhD Thesis, Universiti Putra Malaysia.

Ramachandran, K., V. Srinivasan, S. Hamza and M. Anandaraj, 2005. Phosphate solubilising bacteria isolated from the rhizosphere soil and its growth promotion on black pepper (Piper nigrum L.) cuttings. Proceedings of the 1st International Meeting on Microbial Phosphate Solubilization, (MPS' 03), Springer Netherlands, pp: 325-331. DOI: 10.1007/978-1-4020-5765-6_51

Ramamoorthy, V., R. Viswanathan, T. Raguchander, V. Prakasam and R. Samiyappan, 2001. Induction of systemic resistance by plant growth promoting rhizobacteria in crop plants against pests and diseases. Crop Protect., 20: 1-11. DOI: 10.1016/S0261-2194(00)00056-9

Rashid, M., S. Khalil, N. Ayub, S. Alam and F. Latif, 2004. Organic acids production and phosphate solubilization By Phosphate-Solubilizing Microorganisms (PSM) under in vitro conditions. Pak. J. Biol. Sci., 7: 187-196.

Reinhold-Hurek, B. and T. Hurek 1998. Life in grasses: Diazotrophic endophytes. Trend Microbiol., 6: 139144. DOI: 10.1016/S0966-842X(98)01229-3 
Ribeiro, C.M. and E.J.B.N. Cardoso, 2012. Isolation, selection and characterization of root-associated growth promoting bacteria in Brazil Pine (Araucaria angustifolia). Microbiol. Res., 167: 69-78. DOI: 10.1016/j.micres.2011.03.003

Rodriguez, H. and R. Fraga, 1999. Phosphate solubilizing bacteria and their role in plant growth promotion. Biotechnol. Adv., 17: 319-339. DOI: 10.1016/S0734-9750(99)00014-2

Saharan, B.S. and V. Nehra, 2011. Plant growth promoting rhizobacteria: A critical review. Life Sci. Med. Res., 21: 1-29.

Schwyn, B. and J.B. Neilands, 1987. Universal chemical assay for the detection and determination of siderophores. Analytical Biochem., 160: 47-56. DOI: 10.1016/0003-2697(87)90612-9

Sitepu, I.R., Y. Hashidoko, E. Santoso and S. Tahara, 2007. Potent phosphate-solubilizing bacteria isolated from dipterocarps grown in peat swamp forest in central Kalimantan and their possible utilization for biorehabilitation of degraded peat swamp forest in Central Kalimantan. Proceedings of the International Symposium and Workshop on Tropical Peatland. Aug. 27-29, Yogyakarta, Indonesia.

Somasegaran, P. and H.J. Hoben, 1985. Methods in Legume-Rhizobium Technology. 1st Edn., University of Hawaii NifTAL Project and MIRCEN, pp: 367.

Sugumaran, P. and B. Janarthanam, 2007. Solubilization of potassium containing minerals by bacteria and their effect on plant growth. World J. Agric. Sci., 3: 350-355.

Suzuki, Y., D. Adhikari, K. Itoh and K. Suyama, 2014. Effects of temperature on competition and relative dominance of bradyrhizobium japonicum and bradyrhizobium elkanii in the process of soybean nodulation. Plant Soil, 374: 915-924. DOI: 10.1007/s11104-013-1924-5
Vargas, L., T.L.G.D. Carvalho, P.C.G. Ferreira, V.L.D. Baldani and J.I. Baldani et al., 2012. Early responses of rice (Oryza sativa L.) seedlings to inoculation with beneficial diazotrophic bacteria are dependent on plant and bacterial genotypes. Plant Soil, 356: 127-137. DOI: 10.1007/s11104-012-1274-8

Verma, S.C., J.K. Ladha and A.K. Tripathi, 2001. Evaluation of plant growth promoting and colonization ability of endophytic diazotrophs from deep water rice. J. Biotechnol., 91: 127-141. DOI: 10.1016/S0168-1656(01)00333-9

Vessey, J.K., 2003. Plant growth promoting rhizobacteria as biofertilizers. Plant Soil, 255: 571586. DOI: 10.1023/A:1026037216893

Yanni, Y.G., R.Y. Rizk, V. Corich, A. Squartini and K. Ninke et al., 1997. Natural endophytic association between Rhizobium leguminosarumbv. trifolii and rice roots and assessment of its potential to promote rice growth. Plant Soil, 194: 99-114. DOI: 10.1023/A:1004269902246

Yogesh, K., K.K. Vamsi, B. Amol, G. Nikhil and T. Soham et al., 2009. Study of pectinase production in submerged fermentation using different isolates of Aspergillus Niger. Int. J. Microbiol. Res., 1: 13-17.

Zakry, F.A.A., M.S. Halimi, K.B.A. Rahim, H.A. Osumanu and S.K. Wong et al., 2010. Isolation and plant growth-promoting properties of rhizobacterial diazotrophs from pepper vine (Piper nigrum L.). Malays. Appl. Biol., 39: 41-45.

Zakry, F.A.A., Z.H. Shamsuddin, K.A. Rahim, Z.Z. Zakaria and A.A. Rahim, 2012. Inoculation of Bacillus sphaerichus UPMB-10 to young oil palm and measurement of its uptake of fixed nitrogen using the ${ }^{15} \mathrm{~N}$ isotope dilution technique. Microbes Environ., 27: 257-262. DOI: 10.1264/jsme2.ME11309 